Portland State University

PDXScholar

\title{
A Review of Physiological Simulation Models of Intracranial Pressure Dynamics
}

Wayne W. Wakeland

Portland State University, wakeland@pdx.edu

Brahm Goldstein

Robert Wood Johnson Medical School

Follow this and additional works at: https://pdxscholar.library.pdx.edu/sysc_fac

Part of the Bioinformatics Commons, and the Medical Biomathematics and Biometrics Commons Let us know how access to this document benefits you.

\section{Citation Details}

Wayne Wakeland and Brahm Goldstein, A review of physiological simulation models of intracranial pressure dynamics, Computers in Biology and Medicine, Volume 38, Issue 9, September 2008, Pages 1024-1041.

This Post-Print is brought to you for free and open access. It has been accepted for inclusion in Systems Science Faculty Publications and Presentations by an authorized administrator of PDXScholar. Please contact us if we can make this document more accessible: pdxscholar@pdx.edu. 
Elsevier Editorial System(tm) for Computers in Biology and Medicine Manuscript Draft

Manuscript Number:

Title: A review of physiological simulation models of intracranial pressure dynamics

Article Type: Full Length Article

Keywords: ICP; computer model; intracranial hypertension

Corresponding Author: Dr. wayne wakeland, Ph.D.

Corresponding Author's Institution: Portland State University

First Author: wayne wakeland, Ph.D.

Order of Authors: wayne wakeland, Ph.D.; Brahm Goldstein, MD, MCR

Abstract: This paper reviews the literature regarding the development, testing, and application of physiologybased computer simulation models of intracranial pressure dynamics. Detailed comparative information is provided in tabular format about the model variables and logic, any data collected, model testing and validation methods, and model results. Several syntheses are given that summarize the research carried out by influential research teams and researchers, review important findings, and discuss the methods employed, limitations, and opportunities for further research. 
In 1973, Wayne Wakeland was granted a B.S. in Engineering and Master of Engineering in from Harvey Mudd College. In 1977 he was granted a Ph.D. in Systems Science from Portland State University. In 1978, Wayne became an adjunct member of the core faculty of the Systems Science Ph.D. program, and began teaching a sequence of modeling and simulation courses. In 2000, he became an Associate Professor of Systems Science. Wayne has also held managerial positions in information systems and manufacturing at several high technology firms in Portland. 
Brahm Goldstein attended medical school at the SUNY Health Sciences Center at Syracuse, NY, and did his residency at UCLA in Pediatrics, with additional training at Boston Children's Hospital and Massachusetts General Hospital. From 1986 to 1989 he was an Instructor at the Harvard Medical School. From 1989 to 1994 he was an Assistant Professor at the University of Rochester School of Medicine \& Dentistry; and from 1994 to 2006, he was an Associate Professor at Oregon Health Sciences University, where he also served as Director of Medical Services for the Doernbecher Children's Hospital. He is currently Director, Clinical Research, Biopharmaceuticals at Novo Nordisk, Inc. in Princeton, NJ, and affiliated with the Robert Wood Johnson Medical School. 
None declared

Conflict of Interest Statement (none declared)

None declared 
ICP Modeling Review Paper

\title{
A review of physiological simulation models of intracranial pressure dynamics
}

\begin{abstract}
This paper reviews the literature regarding the development, testing, and application of physiologybased computer simulation models of intracranial pressure dynamics. Detailed comparative information is provided in tabular format about the model variables and logic, any data collected, model testing and validation methods, and model results. Several syntheses are given that summarize the research carried out by influential research teams and researchers, review important findings, and discuss the methods employed, limitations, and opportunities for further research.
\end{abstract}

Key words: ICP, computer model, intracranial hypertension

\section{Article Outline}

Introduction

Methods

Results

Sources and timeline

Detailed findings in tabular format

Discussion

Seminal works and key investigators

Key findings

Findings regarding CSF production and absorption

Findings regarding the relationship between volume and pressure 
ICP Modeling Review Paper

Findings regarding cerebral autoregulation (CAR)

Other findings

Primary computer modeling methods reported

Limitations of current computer models

Future directions

Summary

References

\section{INTRODUCTION}

Elevated intracranial pressure (ICP) is a complex and clinically important pathophysiologic state that is most commonly due to severe traumatic brain injury (TBI), brain tumors, or obstruction of cerebral spinal fluid (CSF) drainage. Current treatment depends on the underlying disease and includes surgical removal of mass lesions, CSF drainage, administration of hypertonic medications, and mild hyperventilation. While patients are often responsive to these therapies, in non-surgical causes of elevated ICP it is unclear which may be most effective. Additionally, it is clear that in some cases repeated uses of the same therapy engenders a tolerance like state where an initial good response becomes less and less effective over time. Thus, there remains a significant need to further discover and evaluate treatments for elevated ICP.

While animal models were the primary historical tool to find ways to improve treatment, researchers have also developed a wide variety of mathematical models in order to attempt to increase understanding of the complex mechanisms that drive ICP dynamics. As computer technology advanced, these models became the basis for computer simulations. The earliest such models appeared in the literature some 35 years ago. Since then many teams of researchers have 
developed a wide variety of mathematical and computer simulation models of ICP dynamics that attempt to reflect to varying degrees the underlying physiology and pathophysiology of elevated ICP. Some of these models are complex and comprehensive while others are simple and focused on one particular aspect, such as cerebrospinal fluid or auto regulatory mechanisms. Some models treat fluid flows and volumes as primary variable, while others focus directly on the pressure gradients. Some models are designed with clinical applications in mind, while others are conceptual or theoretical in nature.

Despite this rich history of computer simulation models related to ICP, this literature has never been comprehensively reviewed. For new researchers entering the field, an authoritative review would be invaluable, and experienced researchers who are focusing on a particular subproblem may benefit from an overview exposure to the work of other researchers.

This review paper is organized as follows. The methods section describes the process for selecting the articles to be included in the review. The results section includes a summary regarding where and when the selected articles were published, followed by a detailed "guide to the literature" in the form of five detailed tables. Table II summarizes the major insights and contributions of each article, organized by first author, and showing co-authors. Table II also lists some of the other authors cited in each paper, along with the total number of citations given, since this information is not provided in the bibliography and may help readers to select articles for further investigation. Table III provides general information regarding whether the model is conceptual or clinically focused, the phenomena investigated, and what experimental data is provided. Table IV gives details of the various models, such as the types of diagrams provided, the number of state variables, time and bandwidth considerations, and key assumptions and logic.

Table V describes model outputs, model testing, and results. For selected articles, Table VI provides additional notes and comments. The discussion section provides a synthesis that includes 
ICP Modeling Review Paper

an abbreviated history regarding the work done by key research teams, a summary of key findings, and an overview of the methods used to support them. The discussion then shifts to the limitations of the research to-date, current challenges faced by researchers, and promising future directions. The article closes with a summary.

\section{METHODS}

The selection of articles combined the results from computerized searches with a previously manually developed d bibliography. The computerized searches utilized both Medline and Compendex (Engineering Village) to assure that articles published in both the medical literature and the engineering literature were located. The primary keywords utilized were "intracranial pressure" \& "simulation," and "intracranial pressure" \& "mathematical model." Many other keywords were experimented with such as "theoretical model," but these did not yield additional relevant articles. Articles prior to 1972 were excluded since they pre-date the widespread application of digital computer simulation. Conference papers were generally not included, except as noted. 106 articles were initially reviewed in detail.

The pearling process involved the exclusion of articles for the following reasons (some articles were excluded for multiple reasons): 11 were focused on head impact (finite element models of brain tissue mechanics); 5 were focused on aneurism or edema; 17 were statistical or used a black box mode rather than physiological; 15 were not actually computer simulation or no model details were provided; 13 did not address ICP specifically; 4 were focused on CSF shunt design; 4 were actually focused on hydrocephalus; and 11 were focused on non-invasive measurement/monitoring. 64 articles remained after these exclusions. Review of the abstracts reduced the number of articles to 50 , of which 40 were deemed to be highly relevant.

The authors had previously and manually accumulated a bibliography on ICP that included 310 articles, of which 210 had been acquired. This bibliography was much broader than just 
ICP Modeling Review Paper

simulation-oriented papers, and had been gleaned in large part from the citations in key articles collected early on. Scanning these 210 articles yielded 31 highly relevant articles on simulation.

Synthesizing the computer search results and the manual ICP simulation bibliography yielded 56 highly relevant works that were reviewed in detail. Most of these are journal articles, but two important dissertations are included, and two articles introducing key concepts were published at International Symposia focused directly on ICP. Three articles were later deleted when they were reviewed more closely, and six articles were subsequently added that were published during 2005-2007 (after the initial literature search had been completed), resulting a total of 59 items from 30 sources.

Each article was reviewed, and information was compiled into several tables to allow for easy comparison of the data, models, assumptions, methods, and findings reported in the articles reviewed.

\section{RESULTS}

\section{Sources and timeline}

Table I shows where the items were published, and Figure 1 indicates when they were published. A strong upward trend is shown, until the year 2000. The volume of articles on this topic appears to have declined somewhat since then.

$<$ Insert Table I and Figure 1 about here $>$

\section{Detailed findings in tabular format}

Table II is organized chronologically by major research team, and provides the year published, lead author, co-authors, the number of references given, selected authors cited, and a summary of the main thrust of each article. Table III provides information on the focus of model 
ICP Modeling Review Paper

(conceptual, clinical, etc.), the phenomenon studied (e.g., TBI, pressure/volume $[\mathrm{P} / \mathrm{V}]$ relationship), and experimental data provided (e.g. ICP, PaCO2, blood flow, pressure volume index [PVI]).

Table IV provides model details, such as the types of diagrams provided (e.g., hydraulic, electrical analog, block diagram), information about state variables, time and bandwidth, key assumptions/logic/constraints, use PVI, and the number and types of autoregulation. Table $\mathbf{V}$ describes the model outputs (e.g., graphs, tables, steady state or transient results, etc.), how the model was validated (e.g., versus experimental/clinical data, or versus data/models in the literature, test simulations, sensitivity analysis, runs with and without cerebral autoregulation [AR], etc.), and what sorts of experimental simulations were run (e. g., treatment options or experimental protocols). Table VI provides additional notes and comments for selected articles.

\section{$<$ Insert Tables II - VI about here $>$}

\section{DISCUSSION}

The following discussion synthesizes the information provided in Tables II-VI, including seminal works and key investigators, important findings, limitations of current models, and promising future directions.

\section{Seminal works and key investigators}

Marmarou's 1973 dissertation [1] and 1978 journal article [2] developed a mathematical model of CSF pressure dynamics, expressed as an electrical analog, which was validated using experiments conducted on cats. He concluded that using a single compartment for CSF is appropriate because there was not a significant pressure gradient between the ventricles and subarachnoid space. CSF formation rate was treated as constant, and CSF absorption was a 
ICP Modeling Review Paper

function of the difference between the CSF pressure and the dural sinus pressure. The resistance associated with this absorption was shown to be constant (not to vary with pressure, as might have been thought). Thus, the response of the system to a rapid injection or withdrawal of CSF fluid is a rapid increase or decrease in pressure followed by a slow return to the baseline pressure. The response curve is fundamentally exponential in nature.

Marmarou's major contribution in this work is the definition of the pressure volume index (PVI) as the amount of fluid which, when rapidly added, causes the pressure to increase by a factor of 10 . In cats with normal physiology this was reported to vary from 0.5 to $1.4 \mathrm{~mL}$. The value is, of course, much larger for humans.

Several non-clinical experiments were conducted using an animal model and compared with the theoretical model. These consisted of a series of small, rapid injections of varying amounts of saline small, somewhat less rapid removals of CSF in various amounts; and a stair-step sequence of saline infusions that simulated changes in the CSF formation rate. These tests all supported the basic formulation of the theoretical model, including the PVI index.

Marmarou also studied the reliability of using a single injection to measure compliance and found that a single injection could be used to estimate the compliance factor $(\mathrm{K})$ to within $\pm 10 \%$, whereas the resistance to absorption could not be accurately estimated from a single injection $(\mathrm{K}=$ $\mathrm{PVI} / \mathrm{P})$.

In 1987, Hoffman [8] provided the first comprehensive intracranial simulation model that included cerebral blood volumes and flow rates, CSF volume and flow rates, baroreceptor-based flow regulation, and regional blood flow. Some relationships were portrayed graphically, rather than functionally. Hoffman was also the first researcher working in this field to demonstrate the use of optimization to estimate unknown parameter values. 
ICP Modeling Review Paper

Ursino (1988-2003) has been the most prolific contributor to the ICP modeling literature, with 19 articles from his research team included in this review.

Ursino [14] described an intracranial simulation model that focused on the shape and pulse amplitude of the ICP waveform. Application and validation was described in subsequent studies [15][16]. Ursino and Di Giammarco [17] describe a major extension to the earlier model, with considerable model detail and a stability analysis. Other investigations that year [18][19] focused on cerebral auto-regulation and reproducing clinically observed oscillations in the ICP waveform such as Lundberg's A and B waves.

Ursino et al [20] described a complex ICP model that had several blood compartments. They also determined and provided basal values for all important model parameters, many of which were derived experimentally. The model included many variable conductances and compliances; and auto-regulation was modeled in detail, including pressure differentials due to muscle tension, vessel wall tension, and viscous forces. The model was fitted to prospectively collected subject-specific data including the ICP response to PVI testing (injection and removal of CSF). The reported fit was very good.

Ursino and Lodi [22] offered a simplified model based on the team's experience with more complex models. The report also discussed the feedback loops in the model and the stability characteristics of the equations. A companion study applied the simpler model to the same prospective data used to fit the more complex model. The simple model worked nearly as well as the more complex model. Additional validation was reported by Lodi et al [24] based on prospective data from a $\mathrm{CO}_{2}$ challenge protocol. Also that year, the model was extended to permit comparison with transcranial Doppler ultrasound (TCD) data [25]. Lodi and Ursino [27] reported on using the model to study cerebral arterial vasospasm, and Russo et al [28] reported on using the model to help explain clinical experiments to measure cerebrovascular reserve. 
ICP Modeling Review Paper

Ursino et al [29] analyzed the changes in cerebral hemodynamics and ICP evoked by challenges in arterial blood pressure (ABP) and $\mathrm{PaCO}_{2}$. These tests used their simpler model aimed at routine clinical investigations. The model was validated by comparing model results (flow in the middle cerebral artery was assumed in the model to be $1 / 3$ of the total cerebral blood flow) with blood velocity measured in the middle cerebral artery via TCD during the challenges. Six model parameters were estimated statistically via least squares fit, including CSF resistance, intracranial elastance, $\mathrm{AR}$ gain, and $\mathrm{CO}_{2}$ reactivity (gain, time constant, and normal set point). A key difference between this model and some of the earlier models was that CSF production was not held constant; rather, it was modulated by variations in CBF.

One of the physiologic challenge protocols that provided the dynamic data needed to estimate model parameters was gradual hyperventilation followed by a period of hypoventilation, and then a return to baseline. A second physiologic challenge utilized a norepinephrine perfusion to change ABP. Once a new ABP was achieved, the $\mathrm{PaCO}_{2}$ challenge was repeated. 44 tracings from 13 patients were obtained and analyzed. Results were quite good in most cases, with the standard deviation of the residuals for $\Delta \mathrm{ICP}$ and $\Delta$ middle cerebral artery blood flow velocity ( $\triangle \mathrm{VMCA})$ being on the order of the measurement error. Any exceptions to these generally favorable results are discussed in detail.

Ursino et al [30] described yet another variation of the model that looked at the microcirculation and was validated using prospective clinical data regarding response of patients with internal carotid artery (ICA) occlusion to $\mathrm{CO}_{2}$ challenges. The so-called cerebral blood flow "steal" phenomenon was demonstrated by the model.

Ursino and Magosso [31] extended the AR aspects of their model to include a third local AR mechanism--tissue hypoxia. The model was used to study how these three AR responses interact. Initially, only the $\mathrm{PaO}_{2}$ response was allowed to act. The resulting vasodilation was 
ICP Modeling Review Paper

insufficient to maintain flow. An additional mechanism was then enabled, still without the $\mathrm{PaCO}_{2}$ response. Thus, four gains were estimated, two for each of the arterial compartments. The two mechanisms together were able to cause sufficient vasodilation, such that the model results matched experimental data where $\mathrm{PaCO}_{2}$ has been held constant. Finally, the $\mathrm{CO}_{2}$ response was activated and various model experiments were run. The first set computed $\mathrm{CO} 2$ reactivity as a function of $\mathrm{PaO}_{2}$, as it varied from hypoxia to hyperoxia. The model reproduced previously published data from rabbit studies showing highly non-linear behavior. This was with ICP held constant (open skull). More runs were made with closed skull conditions. The Lundberg A wave was reproduced, as were long period oscillations. Hemodilution was then studied, with favorable results.

Ursino and Guilioni [32] reported on the use of their mathematical model to develop a CAR index based on the pulse morphology of the TCD velocity waveform that was both sensitive and selective.

Another highly influential team, lead by M. Czosnyka (1992-2001), with J. Pickard and S. Piechnik, published seven of the articles included in this review. Seminal papers in 1993 [34] and 1997 [36] presented an ICP model that treated the blood volume as two compartments (arterial blood storage [a] and capillary plus venous blood storage [v]), with CSF storage [c] as a third compartment. These three volumes were constrained to add up to a fixed volume per the Monro Kellie doctrine. CSF was modeled per Marmarou. The model was shown as an electrical circuit analog, and differential equations were provided for each of the three pressures $\mathrm{Pa}, \mathrm{Pv}$, and $\mathrm{Pi}$ (ICP). In 2001, Piechnik, the principal modeler on the team, published his dissertation [39], which provided a detailed review of the literature on intracranial physiology and models in additional to several chapters organized as independent reports. Our current review is intended to complement that excellent review. 
ICP Modeling Review Paper

The Czosnyka team cites reports describing Ursino's highly complex ICP model. Although the most influential model from the Czosnyka team is attractive for its simplicity and resulting insights, Piechnik's work also included several more complex models to address phenomena such as cerebral blood flow "steal" where asymmetric malformations are not properly compensated for via the Circle of Willis [37]. He also created a physical model to study the appropriateness of the "Starling resistor" model for the bridging veins [38]. This research showed specifically how the Starling resistor model is inappropriate when ICP is less than the saggital sinus pressure, and provided an alternative model. Much of this team's primary work focused on ICP monitoring and hydrocephalus, and therefore was not included in this review.

The final highly productive ICP modeling team, led by W. Lakin, entered the field in 1995 with a strong mathematical focus. Nine of this group's articles are included in this review. Their approach emphasized mathematical approaches to model simplification and steady state initialization. They reference the work by Marmarou, Karni, and Czosnyka, but, curiously, did not reference Ursino until very recently (2005). One very ambitious contribution from this team was a 16-compartment "whole body" model (Lakin et al [45]) that modeled the changes in total intracranial volume rather than invoking the Monroe-Kellie hypothesis. This model was validated by simulating infusion tests and catastrophic events such as the loss of a large fraction of the body's blood.

In 2005, Stevens et al [46] reported on using a simplified version of their 2003 model to study ICP in microgravity conditions (it remained "normal"). The primary method was steady state analysis. Two Stevens et al [47] reported on a further simplified model applied to idiopathic intracranial hypertension (IIH). Stability analysis was performed regarding events that could trigger the transition from a steady state with normal ICP to one with elevated ICP. Stevens et al [48] 
ICP Modeling Review Paper

added a Starling-like resistor to better model the transverse sinus. The model was calibrated such that it perfectly fit the data for three subjects.

Two other very recent papers deserve mention. Gaohua [58] provided an ambitious whole body model focused on the use of hypothermia to treat elevated ICP. Much model detail was provided regarding the equations and parameters, along with some validation tests and a demonstration of using a controller to quickly bring a simulated patient to a target ICP value using hypothermia. Hu et al [59] documented their ambitious work that combined simulation (drawing heavily on Ursino), parameter identification, and intracranial state estimation using extended Kalman filters. The use of these dynamic filters reduced model fit error significantly.

\section{Key findings}

Key findings are grouped as follows: CSF production and absorption, Relationship between pressure and volume, Cerebral autoregulation, and Other findings.

\section{CSF production and absorption}

Marmarou [1][2] supported with animal models the use of a constant CSF formation rate and a constant CSF uptake resistance in simulation models. The resulting graphs for how the system returns to steady state when perturbed are exponential in shape.

Eijndhoven [5] argued that the CSF formation rate is not constant, but based on the pressure differential. Ahearn et al [7] studied this question, but did not provide a conclusive answer supported with empirical data. Hoffman [8] suggested that the CSF formation rate is a function of blood flow volume, not pressure differential.

Ursino et al [29] modeled the CSF production rate as being proportional to the differential between intracranial arterial and capillary pressure. They also reported that the estimated CSF

outflow resistance in their study was significantly elevated from basal values in all but one patient, 
ICP Modeling Review Paper

supporting the general belief that impaired CSF uptake is an important contributor to elevated ICP in a large fraction patients with severe TBI.

\section{Relationship between pressure and volume}

Marmarou [1][2] showed that an exponential equation for the intracranial pressure/volume relationship that features a pressure volume index (PVI, the amount of added fluid that increases pressure by a factor of ten from baseline) is a practical way to model the relationship between volume and pressure. Marmarou also determined that a single mock CSF injection can be used to determine the value of PVI.

Chopp [4] introduced the use of a "Starling" resistor formulation and used the resulting model to clarify the efficacy and meaning of Marmarou's PVI test. Another alternative to PVI is a logistic function (Kadas et al [41], Lakin et al [42][45]). Stevens and Lakin [43] employed an empirical and highly nonlinear $\mathrm{P} / \mathrm{V}$ curve.

Piechnk et al [38] used a physical apparatus and mathematical model to study cerebral venous outflow. He found that the Starling resistor model did not perform well, and provided an alternative. Cirovic et al [56] provided a new volume-pressure test that better reproduced classic results from Chopp[4], and showed that the state of CAR does not have a dominant effect as might be expected.

\section{Cerebral autoregulation (CAR)}

Zagzoule and Marc-Vergnes [6] modeled cerebral blood circulation in 34 segments to study how much vasodilation (via CAR) is needed to maintain flow when ABP is lowered. Ursino [16] reported model results with and without intact CAR. Ursino [18] modeled five distinct CAR mechanisms in the rat (two chemical, one mygenic, and two neurogenic). Czosnyka et al [33] 
ICP Modeling Review Paper

defined a measure termed "state of autoregulation" (SA). Kadas et al [41] modeled CAR as an instantaneous change in vascular resistance.

Ursino et al [30] considered the CAR response to changes in $\mathrm{PaCO}_{2}$ in addition to the $\mathrm{AR}$ response to changes in cerebral blood flow. The two control signals could reinforce the response, or the two signals could modulate each other in some fashion. CAR gain varied from 0.2 (severely impaired) to 1.5 (normal). The authors reported that in some patients CAR was normal, whereas it was below normal in others. This is discussed in terms of the static AR index, sARI (defined as \% change in CVR divided by $\%$ change in cerebral perfusion pressure [CPP]). AR gain and sARI were found to be highly correlated. The $\mathrm{CO}_{2}$ reactivity index ( $\%$ change in $\mathrm{VMCA} /$ change in $\mathrm{PaCO}_{2}$ ) is particularly interesting. The authors show that this index is not representative of the "true" $\mathrm{CO} 2$ reactivity because it depends strongly on CPP. By contrast, the gain associated with $\mathrm{CO}_{2}$ reactivity, $\mathrm{GCO}_{2}$, is quite independent of $\mathrm{CPP}$. The reduced compensatory response to $\mathrm{CO}_{2}$ during hypotension is reflected in their model due to their inclusion of the $\mathrm{CO}_{2}$ component of the CAR response.

A revised model reported by Ursino and Magosso [31] featured three CAR control mechanisms, where the smooth muscle state was adjusted separately for the arteries and the arterioles. As with their previous models, each section of control logic was characterized by a gain parameter and a time constant. An attenuation factor that depended on CBF mediated the $\mathrm{CO}_{2}$ reaction since it normally works to contract rather than dilate the vessels - an effect that is attenuated when $\mathrm{CBF}$ is substantially compromised. The three control signals were then added and passed through an S-shaped function that implements the asymmetric physiological limits to the smooth muscle response. Venous $\mathrm{O}_{2}$ concentration was computed by subtracting from the arterial $\mathrm{O}_{2}$ concentration the brain $\mathrm{O}_{2}$ consumption rate divided by the flow rate. Brain $\mathrm{O}_{2}$ consumption rate was constant for the reported model experiments. $\mathrm{PaO}_{2}$ concentration was computed using 
ICP Modeling Review Paper

parameters and formulae from the literature. The time constant for the $\mathrm{PaO}_{2}$ response was estimated to be $20 \mathrm{~s}$. by assuming that the mechanism works via vasodilatory factors such as adenosine that metabolize in approximately one minute. Ursino and Guilioni [32] demonstrated a sensitive and specific CAR index based on pulse morphology.

\section{Other findings}

Rekate [12] failed to find support for a hypothesis regarding brain "turgor" as a compliance element.

Several researchers (Yu et al [40], Ursino and Lodi [22], Ursino et al [23], Czosnyka et al [33], Stevens et al [47]) found that simple models were often nearly as effective as complex models and were probably more useful because they are easier to understand and ran much faster. Yu specifically suggested treating slowly changing variable as constants.

Lodi et al [24] found support for clinical guidelines to maintain $\mathrm{CPP}>70 \mathrm{mmHg}$. Ursino et al [25], and Ursino and Guilioni [32] used models to help develop non-invasive estimates of ICP and the status of CAR based on shape of the transcranial Doppler (TCD) waveform and other data. Lodi and Ursino [27] showed that TCD measurements alone were not a reliable indicator of arterial vasospasm.

Ursino and Belardinelli [19] and Czosnyka et al [35] reproduced and explained the mechanisms behind Lundberg's A and B waves seen in the clinical environment. Ursino et al [30] and Piechnik et al [37] created models that demonstrate the "steal" phenomena (regarding compensatory response between the left and right hemispheres). Stevens et al [46] showed that ICP was not significantly impacted by microgravity. 
ICP Modeling Review Paper

\section{Primary computer modeling methods reported}

Table $\mathbf{V}$ described model outputs, model testing, and results. In most cases, the primary methods used to establish the findings discussed above included the development and solution of systems of ordinary differential equations (ODEs). In some cases, a set of simultaneous equations were solved instead of or in addition to ODEs.

Another important method involved some form of parameter estimation (sometimes called model identification), where parameters are adjusted (optimized) in order to minimize the error between the model-calculated ICP vs. the actual data. This was first demonstrated by Hoffman [8]. Ursino et al [20][23][24] estimated four parameters in order to create patient-specific models for 18 subjects with very good results, including classification of the patient's CAR status. Ursino et al [29] estimated six parameters to identify patient specific models, with excellent results.

Steady state analysis was first employed in the ICP simulation domain by Karni et al [41]. Related to this, stability analysis and state transition analysis were used by Ursino and Di Giammarco [17], Ursino and Lodi [22], and Stevens et al [48] to better understand normal versus pathophysiological states, and what triggers the shifts between these states.

$\mathrm{Hu}$ et al [59] reported that the addition of a nonlinear filtering method to improve the estimation of hidden state variables in the model dramatically reduces model fit error.

\section{Limitations of Current Computer Models}

In our opinion, the most significant limitation is that virtually no tangible clinical impact has been reported, due in part to the fact that the models are not intuitive, are very complex, and the results are not sufficiently relevant and useful to garner the attention of clinicians.

A related challenge is the limited availability of high quality, annotated, prospective clinical data that is needed to fuel progress in the ICP dynamic modeling field. Some data has been reported, but these data are generally not shared widely within the research community. This might 
ICP Modeling Review Paper

be due in part to the lack of standardized data formats for clinically annotated data, and the lack of incentives and simple mechanisms for sharing data.

\section{Future Directions}

Some teams have experimented with adding more "compartments" (creating whole body models) such as reported in Lakin et al [45] and Gaohua and Kimura [58]. The first of these incorporated $\mathrm{ABP}$ regulation and modeled the larger closed loops that extend outside the cranial cavity, whereas the second team focused on temperature regulation and the effects of hypothermia on ICP.

Bekker [49][50] reported on the integration of PK models and ICP dynamic models, which would seem to hold much promise. More work is needed to continue improve models of primary mechanisms and processes such as CAR in order to improve our understanding of these critical physiological mechanisms.

More carefully annotated prospective data collection is needed to improve model calibration and testing. Many groups report the use of prospective data (e.g., Ursino and others), but practical ways to share the data and generally accepted data format standards are very much needed. We suggest that a central repository such as Physiobank (www.physiobank.org) would be an ideal solution. Datasets need to include physiologic waveform and parametric data, clinical information (e.g. age, sex, type and severity of injury, outcome), and, most importantly, clinical annotations with time stamped information about treatment start and stop times, concurrent medication administration, changes in mechanical ventilation, and detailed laboratory and radiographic test results [60][61].

In order to improve the acceptance of model-based findings by clinicians, model logic must be very carefully explained using simplified diagrams and pictures. The work of Czosnyka et 
ICP Modeling Review Paper

al [34][35], Ursino and Lodi [22], and Wakeland and Goldstein [57] represents a start, but much more progress is needed.

Algorithms are need to quickly "fit" non-specific models to data collected for specific patients, and then identifying promising treatment options for these patients. The hidden state variable estimation methods demonstrated by $\mathrm{Hu}$ et al [57] may lead the way here.

There exists a need to improve models in order to better understand phenomena of secondary mechanisms and secondary insults as discussed by Czosnyka et al [36]. This phenomenon may involve cellular breakdown from prolonged ischemia, or changes in osmotic pressure gradients due to increased quantities of large molecules in the interstitial fluid. This topic was discussed in detail by A. Marmarou at his plenary talk at the ICP2004 Symposium in Hong Kong, but work in this area has been limited. 
ICP Modeling Review Paper

\section{SUMMARY}

Over the past several decades, considerable research has been done to create, validate, and apply computer simulation models of ICP dynamics that strive to reflect the underlying physiology and pathophysiology. The sophistication of the models and the quality of the results has improved significantly as computer hardware and computer simulation software has improved. However, the clinical impact of these models remains negligible, due in part to the lack of substantial databanks of clinically annotated data, and also, of course, to the fact that intracranial physiology and the associated autoregulatory mechanisms are complex and only partially understood.

This paper reviewed 57 central articles and two Ph.D. dissertations covering three decades of research. The paper provided not only detailed tabular information to allow for quick comparison of model details, analysis methods, and results; but also various summaries and syntheses that allow the reader to quickly develop an appreciation for this particular body of literature. The details included the main thrust of each article, and information regarding the phenomenon studied, the experimental data provided, the types of diagrams provided, model state variables, key assumptions/logic/constraints, the types of model outputs provided, how the model was validated, and what sorts of experimental simulations were run, such as different treatment options or experimental protocols.

The discussion section reviewed the seminal articles in more detail, especially the contributions by key investigators and research teams; and also summarized the specific findings regarding CSF production and absorption, the relationship between volume and pressure, different cerebral auto regulation mechanisms, and other topics such as model simplicity and the appropriateness of clinical guidelines regarding the maintenance of cerebral profusion pressure. The computer modeling methods employed were then discussed, as well as the limitations of current computer models, and promising future directions. 
ICP Modeling Review Paper

Significant opportunities for advancement in the field exist, including the possibility for making important clinical contributions, but these depend on several factors: 1) that the requisite data needed to calibrate and validate computer simulation models be collected and disseminated, 2) that additional physiologic mechanisms be incorporated into the models, and 3) that newer, systems-oriented analysis methods be applied in clinically relevant ways. 
ICP Modeling Review Paper

\section{Acknowledgements}

The authors gratefully acknowledge support from the Thrasher Research Fund and from James McNames at the Biological Signal Processing Laboratory at Portland State University. 
ICP Modeling Review Paper

\section{Bibliography}

1. Marmarou, A., A Theoretical Model and Experimental Evaluation of the Cerebrospinal Fluid System. 1973, Drexel University: Philadelphia.

2. Marmarou, A., K. Shulman, and R.M. Rosende, A nonlinear analysis of the cerebrospinal fluid system and intracranial pressure dynamics. Journal of Neurosurgery, 1978. 48(3): p. 332-44.

3. Hakim, S., J.G. Venegas, and J.D. Burton, The physics of the cranial cavity, hydrocephalus and normal pressure hydrocephalus: mechanical interpretation and mathematical model. Surgical Neurology, 1976. 5(3): p. 187-210.

4. Chopp, M., H.D. Portnoy, and C. Branch, Hydraulic model of the cerebrovascular bed: an aid to understanding the volume-pressure test. Neurosurgery, 1983. 13(1): p. 5-11.

5. Eijndhoven, J.H.M.v. and C.J.J. Avezaat, New aspects of cerebrospinal fluid circulation models with emphasis on the stability of the model parameters, in Intracranial Pressure V, S. Ishii, H. Nagai, and M. Brock, Editors. 1983, Springer-Verlag: Berlin. p. 227-233.

6. Zagzoule, M. and J.P. Marc-Vergnes, A global mathematical model of the cerebral circulation in man. J. Biomechanics, 1986. 19(12): p. 1015-22.

7. Ahearn, E.P., et al., Two compartment model of the cerbrspinal fluid system for the study of hydrocephalus. Annals of Biomedical Engineering, 1987. 15(5): p. 467-484.

8. Hoffmann, O., Biomathematics of intracranial CSF and haemodynamics. Simulation and analysis with the aid of a mathematical model. Acta Neurochirurgica - Supplementum, 1987. 40: p. 117-30.

9. Karni, Z., et al., Quasi-steady-state compartmental model of intracranial fluid dynamics. Medical \& Biological Engineering \& Computing, 1987. 25(2): p. 167-72.

10. Sorek, S., J. Bear, and Z. Karni, Non-steady compartmental flow model of the cerebrovascular system. Journal of Biomechanics, 1988. 21(9): p. 695-704.

11. Takamae, A simulation study of intracranial pressure increment using an electrical circuit model of cerebral circulation. IEEE Trans Biomed Eng, 1987. 
12. Rekate, H.L., et al., Ventricular volume regulation: a mathematical model and computer simulation. Pediatric Neuroscience, 1988. 14(2): p. 77-84.

13. Rekate, H.L., The usefulness of mathematical modeling in hydrocephalus research. Childs Nervous System, 1994. 10(1): p. 13-8.

14. Ursino, M., A mathematical study of human intracranial hydrodynamics. Part 1--The cerebrospinal fluid pulse pressure. Annals of Biomedical Engineering, 1988. 16(4): p. 379-401.

15. Ursino, M., A mathematical study of human intracranial hydrodynamics. Part 2--Simulation of clinical tests. Annals of Biomedical Engineering, 1988. 16(4): p. 403-16.

16. Ursino, M., Computer analysis of the main parameters extrapolated from the human intracranial basal artery blood flow. Computers \& Biomedical Research, 1990. 23(6): p. 542-59.

17. Ursino, M. and P. Di Giammarco, A mathematical model of the relationship between cerebral blood volume and intracranial pressure changes: the generation of plateau waves. Annals of Biomedical Engineering, 1991. 19(1): p. 15-42.

18. Ursino, M., A mathematical model of overall cerebral blood flow circulation in the rat. IEEE Trans Biomed Eng, 1991.

19. Ursino, M. and E. Belardinelli, Knowledge-oriented modeling of cerebrovascular control mechanisms. Comments Theoretical Biology, 1991. 2(3): p. 211-237.

20. Ursino, M., M. Iezzi, and N. Stocchetti, Intracranial pressure dynamics in patients with acute brain damage: a critical analysis with the aid of a mathematical model. IEEE Transactions on Biomedical Engineering, 1995. 42(6): p. 529-40.

21. Giulioni, M. and M. Ursino, Impact of cerebral perfusion pressure and autoregulation on intracranial dynamics: a modeling study. Neurosurgery, 1996. 39(5): p. 1005-14; discussion 10145.

22. Ursino, M. and C.A. Lodi, A simple mathematical model of the interaction between intracranial pressure and cerebral hemodynamics. Journal of Applied Physiology, 1997. 82(4): p. 1256-69.

23. Ursino, M., et al., Intracranial pressure dynamics in patients with acute brain damage. Journal of Applied Physiology, 1997. 82(4): p. 1270-82. 
ICP Modeling Review Paper

24. Lodi, C.A., et al., Modeling cerebral autoregulation and CO2 reactivity in patients with severe head injury. American Journal of Physiology, 1998. 274(5 Pt 2): p. H1729-41.

25. Ursino, M., M. Giulioni, and C.A. Lodi, Relationships among cerebral perfusion pressure, autoregulation, and transcranial Doppler waveform: a modeling study. Journal of Neurosurgery, 1998. 89(2): p. 255-66.

26. Ursino, M. and C.A. Lodi, Interaction among autoregulation, CO2 reactivity, and intracranial pressure: a mathematical model. American Journal of Physiology, 1998. 274(5 Pt 2): p. H1715-28.

27. Lodi, C.A. and M. Ursino, Hemodynamic effect of cerebral vasospasm in humans: a modeling study. Annals of Biomedical Engineering, 1999. 27(2): p. 257-73.

28. Russo, G., C.A. Lodi, and M. Ursino, Quantitative assessment of cerebral vascular reserve by means of transcranial Doppler ultrasound and rebreathing maneuver: bedside test and mathematical modeling. Neurological Sciences, 2000. 21(5): p. 292-302.

29. Ursino, M., et al., Cerebral hemodynamics during arterial and CO(2) pressure changes: in vivo prediction by a mathematical model. American Journal of Physiology - Heart \& Circulatory Physiology, 2000. 279(5): p. H2439-55.

30. Ursino, M., C.A. Lodi, and G. Russo, Cerebral hemodynamic response to CO(2) tests in patients with internal carotid artery occlusion: modeling study and in vivo validation. Journal of Vascular Research, 2000. 37(2): p. 123-33.

31. Ursino, M. and E. Magosso, Role of tissue hypoxia in cerebrovascular regulation: a mathematical modeling study. Annals of Biomedical Engineering, 2001. 29(7): p. 563-74.

32. Ursino, M. and M. Giulioni, Quantitative assessment of cerebral autoregulation from transcranial Doppler pulsatility: a computer simulation study. Medical Engineering \& Physics, 2003. 25(8): p. $655-66$.

33. Czosnyka, M., et al., The hyperaemic response to a transient reduction in cerebral perfusion pressure. A modelling study. Acta Neurochirurgica, 1992. 115(3-4): p. 90-7.

34. Czosnyka, M., et al., CO2 cerebrovascular reactivity as a function of perfusion pressure--a modelling study. Acta Neurochirurgica, 1993. 121(3-4): p. 159-65. 
ICP Modeling Review Paper

35. Czosnyka, M., S. Piechnik, and a. et, The dynamics of cerebral blood flow, perfusion pressure and CSF circulation - a modelling study, in Intracranial Pressure VIII. 1993, Springer-Verlag: Berlin.

36. Czosnyka, M., et al., Contribution of mathematical modelling to the interpretation of bedside tests of cerebrovascular autoregulation. Journal of Neurology, Neurosurgery \& Psychiatry, 1997. 63(6): p. 721-31.

37. Piechnik, S.K., et al., A model of the cerebral and cerebrospinal fluid circulations to examine asymmetry in cerebrovascular reactivity. Journal of Cerebral Blood Flow \& Metabolism, 2001. 21(2): p. 182-92.

38. Piechnik, S.K., et al., Cerebral venous blood outflow: a theoretical model based on laboratory simulation. Neurosurgery, 2001. 49(5): p. 1214-22; discussion 1222-3.

39. Piechnik, S., A mathematical and biophysical modellingof cerebral blood flow and cerebrospinal fluid dynamics. 2001, University of Cambridge: Cambridge.

40. Yu, J., W.D. Lakin, and P.L. Penar, A hybrid asymptotic-numerical study of a model for intracranial-pressure dyanmics. Studies in Applied Mathematics, 1995. 95(3): p. 247-267.

41. Kadas, Z.M., et al., A mathematical model of the intracranial system including autoregulation. Neurological Research, 1997. 19(4): p. 441-50.

42. Lakin, W.D.Y., J. et al, Analysis and validation of a mathematical model for intracranial pressure dynamics. Mathematical and Computer Modeling of Dynamical Systems, 1999. 5(1): p. 55-73.

43. Stevens, S.A. and W.D. Lakin, Local Compliance Effects on the Global Pressure-Volume Relationship in Models of Intracranial Pressure Dynamics. Mathematical and Computer Modeling of Dynamical Systems, 2000. 6(4): p. 445-465.

44. Stevens, S.A., Mean pressures and flows in the human intracranial system as determined by mathematical simulations of a steady-state infusion test. Neurological Research, 2000. 22(8): p. 809-14.

45. Lakin, W.D., et al., A whole-body mathematical model for intracranial pressure dynamics. Journal of Mathematical Biology, 2003. 46(4): p. 347-83. 
ICP Modeling Review Paper

46. Stevens, S.A., W.D. Lakin, and P.L. Penar, Modeling steady-state intracranial pressures in supine, head-down tilt and microgravity conditions. Aviat Space Environ Med, 2005. 76(4): p. 329-38.

47. Stevens, S.A., et al., Idiopathic intracranial hypertension and transverse sinus stenosis: a modelling study. Math Med Biol, 2007. 24(1): p. 85-109.

48. Stevens, S.A., et al., A modeling study of idiopathic intracranial hypertension. Neurological Research, 2007. in press.

49. Bekker, A., et al., Computer simulation of cerebrovascular circulation: assessment of intracranial hemodynamics during induction of anesthesia. Journal of Clinical Monitoring, 1996. 12(6): p. 43344.

50. Bekker, A.Y., et al., Computer simulation of intracranial pressure changes during induction of anesthesia: comparison of thiopental, propofol, and etomidate. Journal of Neurosurgical Anesthesiology, 1999. 11(2): p. 69-80.

51. Gao, E., et al., A theoretical model of cerebral hemodynamics: application to the study of arteriovenous malformations. Journal of Cerebral Blood Flow \& Metabolism, 1997. 17(8): p. 90518.

52. Gao, E. and e. al, Mathematical consideration for modeling cerbral blood flow AR to SAP. AJP, 1998. 98: p. H1023-H1031.

53. Bergsneider, M., et al., The relationship of pulsatile cerebrospinal fluid flow to cerebral blood flow and intracranial pressure: a new theoretical model. Acta Neurochirurgica - Supplementum, 1998. 71: p. 266-8.

54. Thoman, W.J., et al., A computer model of intracranial dynamics integrated to a full-scale patient simulator. Computers \& Biomedical Research, 1998. 31(1): p. 32-46.

55. Thoman, W.J., et al., Autoregulation in a simulator-based educational model of intracranial physiology. Journal of Clinical Monitoring \& Computing, 1999. 15(7-8): p. 481-91.

56. Cirovic, S., C. Walsh, and W.D. Fraser, Mathematical study of the role of non-linear venous compliance in the cranial volume-pressure test. Medical \& Biological Engineering \& Computing, 2003. 41(5): p. 579-88. 
ICP Modeling Review Paper

57. Wakeland, W. and B. Goldstein, A computer model of intracranial pressure dynamics during traumatic brain injury that explicitly models fluid flows and volumes. Acta Neurochir Suppl, 2005. 95: p. 321-6.

58. Gaohua, L. and H. Kimura, A mathematical model of intracranial pressure dynamics for brain hypothermia treatment. J Theor Biol, 2006. 238(4): p. 882-900.

59. Hu, X., et al., Estimation of hidden state variables of the intracranial system using constrained nonlinear Kalman filters. IEEE Transactions on Biomedical Engineering, 2007. 54(4): p. 597-610.

60. Goldstein B, McNames J, McDonald BA, Ellenby M, Lai S, Sun Z, Krieger D, Sclabassi RJ. A physiologic data acquisition system and database for the study of disease dynamics in the intensive care unit. Crit Care Med 2003;31:433-441.

61. Vinecore K, Aboy M, McNames J, Phillips C, Ellenby M, Goldstein B. Design and implementation of a portable data acquisition system (PDAS) for physiologic signals in the intensive care unit. Ped Crit Care Med 2007 (in press). 
Table I: Journal or source for the articles reviewed

\begin{tabular}{|l|l|}
\hline Journal or Source & Count \\
\hline Annals of Biomedical Engr & 6 \\
\hline Acta Neurochirurgica & 5 \\
\hline IEEE Trans Biomed Engr & 4 \\
\hline AJP & 4 \\
\hline Neurological Research & 3 \\
\hline Neurosurgery & 3 \\
\hline Medical \& Biological Engineering \& Computing & 2 \\
\hline J. of Cerebral Blood Flow \& Metabolism & 2 \\
\hline $\begin{array}{l}\text { Mathematical and Computer Modeling of Dynamical } \\
\text { Systems }\end{array}$ & 2 \\
\hline J. Neurosurgery & \\
\hline J. of Biomechanics & 2 \\
\hline Computers \& Biomedical Research & 2 \\
\hline J. of Applied Physiology & 2 \\
\hline J.of Clinical Monitoring [and Computing] & 2 \\
\hline Dissertations & 2 \\
\hline ICP Symposia papers & 2 \\
\hline J. of Neurosurgical Anesthesiology & 2 \\
\hline J. of Neurology, Neurosurgery\& Psychiatry & 1 \\
\hline Surgical Neurology & 1 \\
\hline J. of Mathematical Biology & 1 \\
\hline Pediatric Neuroscience & 1 \\
\hline Childs Nervous System & 1 \\
\hline Neurological Sciences & 1 \\
\hline J. of Vascular Research & 1 \\
\hline Medical Engineering \& Physics & 1 \\
\hline Comments Theoretical Biology & 1 \\
\hline Studies in Applied Mathematics & 1 \\
\hline Mathematical Medicine and Biology & 1 \\
\hline J. of Theoretical Biology & 1 \\
\hline Aviation, Space, and Environmental Medicine & 1 \\
\hline & 1 \\
\hline & \\
\hline
\end{tabular}


ICP Modeling Review Paper

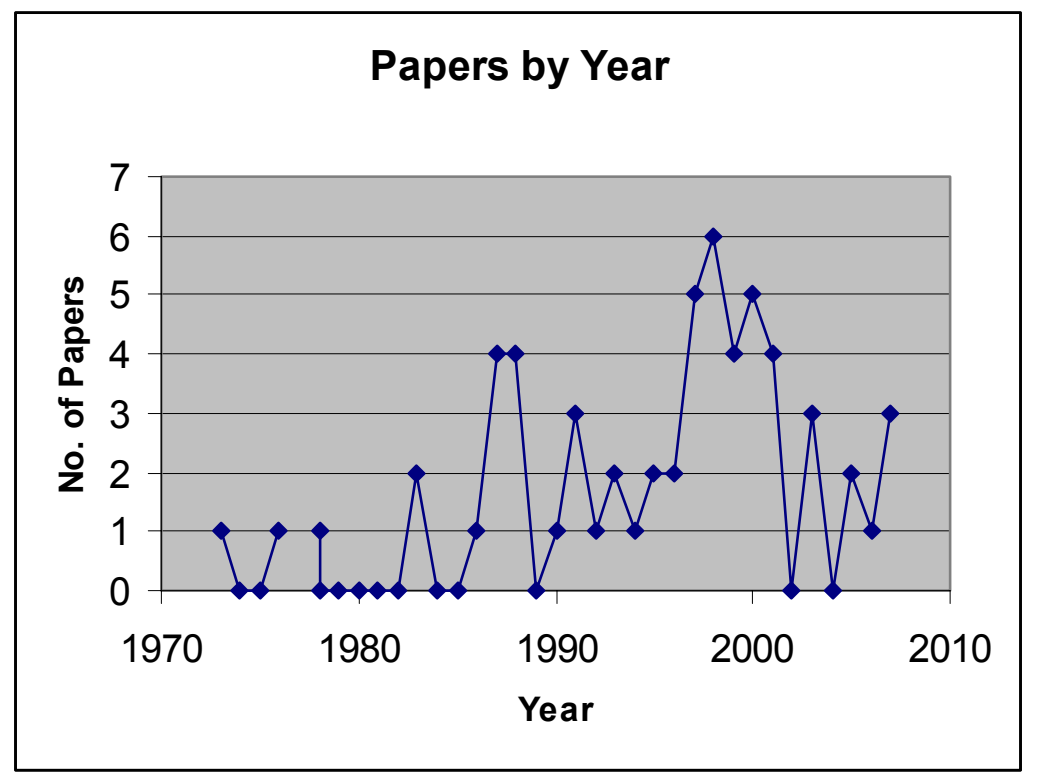

Figure 1: Number of articles by year of publication 
Table II. Major insights and contributions of each article, grouped by research team, and sorted by when each team entered the field.

\begin{tabular}{|c|c|c|c|c|c|c|}
\hline \# & Year & $\begin{array}{l}\text { Lead } \\
\text { Author }\end{array}$ & Co-authors & \begin{tabular}{|l|l|l} 
& \\
Cits
\end{tabular} & Other authors cited (sel.) & Major insights, contributions \\
\hline 1 & 1973 & $\begin{array}{l}\text { Marmarou, } \\
\text { A. }\end{array}$ & & 31 & Davson $65,67,72$ & $\begin{array}{l}\text { First simulation model of CSF dynamics (hydrocephalus focus.). Studies PV relationship and } \\
\text { introduces concept of PVI ( } 1 \mathrm{ml} \text { in cats) as a measure of lumped cranial compliance, and } \\
\text { also defines infusion test to measure PVI and CSF uptake resistance. Validated vs. animal } \\
\text { model, clinical case, and physical model. Determines if single mock CSF injection could be } \\
\text { sufficient to estimate PVI. }\end{array}$ \\
\hline 2 & 1978 & $\begin{array}{l}\text { Marmarou, } \\
\text { A. }\end{array}$ & $\begin{array}{l}\text { Shulman K, Rosende } \\
\text { RM }\end{array}$ & & $\begin{array}{l}\text { Guinane } 72, \text { Lofgren } 73, \\
\text { Benabid } 75, \text { Hofferberth } 75\end{array}$ & $\begin{array}{l}\text { Seminal work on mathematical modeling of CSF dynamics; clearly defines key variables and } \\
\text { parms; explains PVI and methods for est. Ro and PVI. Carefully validated against animal } \\
\text { models, showing model vs. actual data for cat. Clinical relevance discussed. Several useful } \\
\text { tables and data. }\end{array}$ \\
\hline 3 & 1976 & Hakim, S. & Venegas JG, Burton JD & 20 & Marmarou 73 & $\begin{array}{l}\text { Mathematical model of intracranial cavity, including brain parenchyma, ventricles, dura, etc., } \\
\text { focused on hydrocephalus. Also includes physical models and clinically collected } \\
\text { experimental data. }\end{array}$ \\
\hline 4 & 1983 & Chopp, M. & Portnoy H, Branch C & & $\begin{array}{l}\text { Avezaat } 79, \text { Lofgren } 73 \\
\text { Marmarou } 737578\end{array}$ & $\begin{array}{l}\text { Clarify form of P-V curve via hydraulic "Starling" resistor model. Curve is similar to Lofgren } \\
\text { data except at extremes. Suggests that PVI test is NOT an indicator of intracranial } \\
\text { elastance, but rather venous outflow resistance }\end{array}$ \\
\hline 5 & 1983 & $\begin{array}{l}\text { Eijndhoven } \\
\text {, J. }\end{array}$ & Avezaat C. & & Marmarou 73 & $\begin{array}{l}\text { Alternative CSF model (vs. Marmarou); CSF formation is a function of pressure differential } \\
\text { (not constant) }\end{array}$ \\
\hline 6 & 1986 & $\begin{array}{l}\text { Zagzoule, } \\
\text { M. }\end{array}$ & Marc-Vergnes J & & $\begin{array}{l}\text { Kontos } 78, \text { Hillen } 82, \text { Lassen } \\
59\end{array}$ & $\begin{array}{l}\text { Models cerebral circulation using } 34 \text { segments. Given pulsatile input, flows and pressures in } \\
\text { all segments are computed and shown to match physiological measurements. AR is } \\
\text { investigated by lowering ABP and finding how much vasodilation is needed in different } \\
\text { segments. }\end{array}$ \\
\hline 7 & 1987 & $\begin{array}{l}\text { Ahearn, } \\
\text { E.P. }\end{array}$ & $\begin{array}{l}\text { Randall KT, Charlton JD, } \\
\text { Johnson RN }\end{array}$ & & $\begin{array}{l}\text { Argarwal } 69 \text {, Guinane } 72, \\
\text { Hofferberth } 75, \text { Marmarou } \\
75,78, \text { Shapiro } 80,85\end{array}$ & $\begin{array}{l}\text { Provides electrical circuit and control system model for CSF ventricles and subarachnoid } \\
\text { CSF storage. Considers impact of constant vs. pressure-driven CSF formation rate and } \\
\text { constant vs. pressure-sensitive compliance (as possible control mech.) Also, considers } \\
\text { effects of pulsatility. Var. formation response is probably S/T only. Impact of var. compliance } \\
\text { may be complicated by variable outflow resistance. No one factor explains "creep" in PVI. } \\
\text { There may be a critical Pv-Ps value beyond which perm. deformation of CSF ventricles } \\
\text { occurs. Pulsations may exacerbate this effect. }\end{array}$ \\
\hline 8 & 1987 & $\begin{array}{l}\text { Hoffman, } \\
\text { O. }\end{array}$ & & & \begin{tabular}{|l|} 
Eijndhoven 80,86, Hakim 76, \\
Avezaat 87,76, Lofgren 73 \\
Benabid 85, Marmarou 78 \\
\end{tabular} & $\begin{array}{l}\text { Most comprehensive pre-Ursino simulation model of cerebral blood and CSF dynamics, } \\
\text { including heart and baroreceptor regulation. Some key equations are essentially graphical, } \\
\text { expressed mathematically (CVRA and CA). Also considers regional blood flow. CSF } \\
\text { formation rate }=\text { fn. of flow (Hoffman 82: flow thru choriod plexus }=\text { fn of total flow based on } \\
\text { poly. fit to data). Studies influence of ABP on ICP-PP relationship and volume pressure test. } \\
\text { Parameter est. via opt. also demonstrated. }\end{array}$ \\
\hline 9 & 1987 & Karni, Z. & $\begin{array}{l}\text { Bear J, Sorek S, } \\
\text { Pinczewski Z }\end{array}$ & 17 & $\begin{array}{l}\text { Chopp } 80, \text { Hakim } 76 \\
\text { Lundberg } 74, \text { Marmarou } 75\end{array}$ & $\begin{array}{l}\text { Seven compartment mathematical model that particularly separates choroid plexus from rest } \\
\text { of capillary bed and uses } 3 \text { venous compartments. Clear explanation of steady state } \\
\text { parameter values. Finds resonant frequency consistent with Lundberg's "B" waves }(.144 \mathrm{~Hz}) \text {. }\end{array}$ \\
\hline 10 & 1988 & Sorek, S. & Bear J, Karni Z & 20 & $\begin{array}{l}\text { Chopp 80, Davson 60, Hakim } \\
76, \text { Marmarou } 75\end{array}$ & $\begin{array}{l}\text { Additional mathematical analysis based on prior compartmental model (Karni } 87 \text { ) to address } \\
\text { non-steady flow case. Mentions model findings that are documented elsewhere. }\end{array}$ \\
\hline 11 & 1987 & $\begin{array}{l}\text { Takemae, } \\
\text { T. }\end{array}$ & $\begin{array}{l}\text { Kosugi Y, Ikebe J, } \\
\text { Kumagai Y, Matsuyama } \\
\text { K, Saito H }\end{array}$ & & Agarwal 69, Marmarou 75 & $\begin{array}{l}\text { Simulation study based on electrical circuit of cerebral blood and CSF flow inspired by } \\
\text { Agarwal circuit and focused on impact of mean ICP on ICP pulse wave shape. Goal is non- } \\
\text { invasive ICP estimate. }\end{array}$ \\
\hline
\end{tabular}


Table II. Major insights and contributions of each article, grouped by research team, and sorted by when each team entered the field.

\begin{tabular}{|c|c|c|c|c|c|c|}
\hline \# & Year & $\begin{array}{l}\text { Lead } \\
\text { Author }\end{array}$ & Co-authors & \begin{tabular}{|l|} 
Cits \\
\end{tabular} & Other authors cited (sel.) & Major insights, contributions \\
\hline 12 & 1988 & $\begin{array}{l}\text { Rekate, } \\
\text { H.L. }\end{array}$ & $\begin{array}{l}\text { Brodkey JA, Chizeck HJ, } \\
\text { Sakka WE, Ko WH }\end{array}$ & & $\begin{array}{l}\text { Agarwal 69, Marmarou } \\
73,75,78, \text { Ahearn } 87 \\
\text { Guinane } 72, \text { Hakim } 85\end{array}$ & $\begin{array}{l}\text { Seven compartment multiple ventricle CSF model applied to hydrocephalus, especially NPH } \\
\text { and pseudotumor celebri. Plausible parameters reproduce the indicated effects, although the } \\
\text { model is not fully validated. Hypothesized } \mathrm{Kb}=\text { brain turgor. }\end{array}$ \\
\hline 13 & 1994 & $\begin{array}{l}\text { Rekate, } \\
\text { H.L. }\end{array}$ & & 15 & & $\begin{array}{l}\text { Application of } 1988 \text { model, validated with animal data. Insight: Pressures in all CSF } \\
\text { compartments were equal; could not support Kb. Applied to pediatrics cases with diffuse } \\
\text { head injury that did not respond to standard therapy. Similarity to pseudotumor celebri } \\
\text { exploited with success. }\end{array}$ \\
\hline 14 & 1988 & Ursino, M. & & & $\begin{array}{l}\text { Marmarou } 78 \text {, Chopp } 82, \\
\text { Hyashi } 80 \text {, Portnoy } 82 \\
\text { Hoffman } 83\end{array}$ & $\begin{array}{l}\text { Describes intracranial model in detail. Focused on application of ICP pulse amplitude and } \\
\text { wave form shape as a function of ICP. PA is nonlinear with mean ICP due to highly nonlinear } \\
\text { compliances as a function of ICP. }\end{array}$ \\
\hline 15 & 1988 & Ursino, $\mathrm{M}$. & & & $\begin{array}{l}\text { Belardinelli } 85, \text { Miller } 72, \\
\text { Eijndhoven } 83,86, \text { Guilioni } 86, \\
\text { Avezaat } 79, \text { Eksted } 77,78\end{array}$ & $\begin{array}{l}\text { Application and validation of author's } 1988 \text { ICP dynamic model to study the shape of blood } \\
\text { flow velocity wave form, response to CSF infusion and bolus injection, and venous } \\
\text { obstruction. Good agreement with data from literature in all cases. }\end{array}$ \\
\hline 16 & 1990 & Ursino, M. & & 32 & $\begin{array}{l}\text { Aaslid 82,86, Guilioni 88, Marmarou } \\
75,78, \text { Avezaat } 79 \text {, Ekstedt } 77-78\end{array}$ & $\begin{array}{l}\text { Applies prior model, adding simulated pulsatility index and Pourecelot index, and showing the } \\
\text { diastolic and systolic pulse height with and without AR as a function of ICP. }\end{array}$ \\
\hline 17 & 1991 & Ursino, $M$. & Giammarco P Di & & $\begin{array}{l}\text { Kontos } 78 \text {, Auer } 8487 \text {, MacKenzie } 79, \\
\text { Avezaat } 83 \text {, Hayashi } 8086, \text { Hoffman } \\
\text { 87, Rosner 84, Lundberg } 6068 \text {, Sorek } \\
89\end{array}$ & $\begin{array}{l}\text { Major extension of } 1988 \text { model to differentiate AR at arteries vs. arterioles, allowing plateau } \\
\text { waves to be generated. Much discussion of model logic, equations, and parameter values. } \\
\text { Also includes stability analysis of system equations showing parameter values that lead to } \\
\text { instability. }\end{array}$ \\
\hline 18 & 1991 & Ursino, $\mathrm{M}$. & & 49 & Heistad 78,83, Kontos 78,85 & $\begin{array}{l}\text { Detailed mathematical/simulation model of CAR in the rat including five mechanisms--two } \\
\text { chemical, one myogenic, and two neurogenic--each acting on three of five compartments. } \\
\text { Does not include interactions between the various volumes. Compares favorably with } \\
\text { literature data. }\end{array}$ \\
\hline 19 & 1991 & Ursino, $\mathrm{M}$. & Belardinelli E & & $\begin{array}{l}\text { Kontos } 78 \text {, Osol } 85, \text { Marmarou } 73, \\
\text { Winn } 79, \text { Hoffman } 87, \text { Betz } 78 \\
\text { Sercombe } 79, \text { Kuchinisky } 75\end{array}$ & $\begin{array}{l}\text { Reports results of two earlier studies/models, with emphasis on reproducing lab. and clinical } \\
\text { results including oscillations such as Lundberg's A and B waves. }\end{array}$ \\
\hline 20 & 1995 & Ursino, M. & lezzi M, Stochetti N & & $\begin{array}{l}\text { Hoffman } 87 \text {, Sorek } 89 \text {, Takame } 87 \\
\text { Mamarou } 7578878991 \text {, Avezaat } 79 \\
8486, \text { Kosteljanetz } 8487\end{array}$ & $\begin{array}{l}\text { Applied prev. model to prospectively-collected clinical data on } 18 \text { subjects during CSF } \\
\text { inj./removal. Model fit to each subj. by modifying only } 4 \text { parameters. Fit is very good, despite } \\
\text { paradoxical responses in many subjects. Results contrasted with Marmarou. }\end{array}$ \\
\hline 21 & 1996 & Guilioni, M. & Ursino M & 17 & Kontos 78, Rossner 8487 & $\begin{array}{l}\text { Ursino model run to show impact of hypotension in normal vs. pathophysiological cases } \\
\text { (increased CSF uptake resistance and impaired AR) }\end{array}$ \\
\hline 22 & 1997 & Ursino, M. & Lodi CA & & $\begin{array}{l}\text { Hoffman 87, Sorek 89, Mamarou } 75 \\
78 \text { 87 89 91, Avezaat } 798486, \\
\text { Kosteljanetz } 8487 \text {, Rossner } 848790 \text {, } \\
\text { Gray 87, Chopp 83, Czosnyka } 93\end{array}$ & $\begin{array}{l}\text { Much simplified model is nevertheless able to show instability and oscillation, ICP response } \\
\text { to acute SAP reduction, and paradoxical response to PVI tests. Clarifies possible FB loops } \\
\text { and show limit cycle and bifurcation plots. Much sensitivity analysis. }\end{array}$ \\
\hline 23 & 1997 & Ursino, M. & $\begin{array}{l}\text { Lodi CA, Rossi, S, } \\
\text { Stochetti N }\end{array}$ & & $\begin{array}{l}\text { Gray } 87, \text { Kosteljanetz } 84 \text {, } \\
\text { Marmarou } 7578 \text { 87, Rossner } 84 \text {, } \\
\text { Aaslid } 8991 \text {, Avezaat } 79\end{array}$ & $\begin{array}{l}\text { Applies ' } 97 \text { (simpler) model to prospective clinical data that was previously analyzed with } \\
\text { more complex model. New model works very well and is much faster. Parameters estimated } \\
\text { for specific patients, and patients classified as to AR status }\end{array}$ \\
\hline 24 & 1998 & Lodi, C.A. & $\begin{array}{l}\text { Minassian AT, Beydon L, } \\
\text { and Ursino M }\end{array}$ & & Guilioni 96, Rosner 87 & $\begin{array}{l}\text { Validation of previously reported model using an experimental protocol (CO2 challenges) to } \\
\text { collect prospective clinical data. Model parameters are estimated to minimize error in } \\
\text { predicteed ICP and blood flow. Very encouraging results. Supports recommendation of } \\
\text { maintaining CPP greater than } 70-80 \mathrm{mmHg} \text {. Improves knowledge of how AR mechanisms } \\
\text { interact. }\end{array}$ \\
\hline
\end{tabular}


Table II. Major insights and contributions of each article, grouped by research team, and sorted by when each team entered the field.

\begin{tabular}{|c|c|c|c|c|c|c|}
\hline \# & Year & $\begin{array}{l}\text { Lead } \\
\text { Author }\end{array}$ & Co-authors & \begin{tabular}{|l|l|l} 
& \\
Cits
\end{tabular} & Other authors cited (sel.) & Major insights, contributions \\
\hline 25 & 1998 & Ursino, $M$. & Guilioni M, Lodi CA & & \begin{tabular}{|l|} 
Auer 87, Czosnyka 94 96, Gray 87, \\
Hyashi 80, Klingelhofer 8891, Kontos \\
78 89, Marmarou 75, Rossner 8495 \\
\end{tabular} & $\begin{array}{l}\text { Extends } 88 \text { (complex) model model to calculate MCA velocity in order to interpret TCD data. } \\
\text { Mono exponential rel. between vessel radii and transmural pressure. Computes TCD indices } \\
\text { and flow as fn. of ICP, MSAP, CPP. Concludes that mean, peak-peak, and PI (pulsatility } \\
\text { index) must be considered }\end{array}$ \\
\hline 26 & 1998 & Ursino, $M$. & Lodi CA & & $\begin{array}{l}\text { Marmarou } 75 \text {, Lundberg } 60 \\
\text { Rossner } 87 \text {, Kontos } 78 \text {, Wei } \\
80, \text { Harper } 656684\end{array}$ & $\begin{array}{l}\text { Extends ' } 88 \text { model to calc. MCA velocity and separates arteries into two compartments, each } \\
\text { with different regulatory mechanisms. Applies model to show effects of SAP changes and } \\
\mathrm{CO} 2 \text { pressure changes, thereby clarifying how they interact. Model results compare favorably } \\
\text { with data from literature. }\end{array}$ \\
\hline 27 & 1999 & Lodi, C.A. & Ursino M & & $\begin{array}{l}\text { Sorek } 89, \text { Aaslid } \\
82,84,89,91, \text { Avedzaat } 79 \\
\text { Czosnyka } 92,93, \text { Kadas } 97 \\
\text { Marmarou } 78\end{array}$ & $\begin{array}{l}\text { Extends prior model to study vasospasm by subdividing blood compartments. Addresses the } \\
\text { question "is TCD reliable for estimating vasospasm?" Thorough discussion of model logic, } \\
\text { parameters, and validation, including sensitivity analysis. Suggests TCD measurements } \\
\text { alone may not be a reliable indicator of flow when vasospasm is possible or likely. Well } \\
\text { supported with citations from literature. }\end{array}$ \\
\hline 28 & 2000 & Russo, G. & Lodi CA, Ursino M & 37 & Aaslid 82, Smielewski 97 & $\begin{array}{l}\text { Applies existing simulation model to explain clinical experiments to measure cerebrofascular } \\
\text { reserve using a relative } \mathrm{CO} 2 \text { reactivity measure. Serves to help validate the model. }\end{array}$ \\
\hline 29 & 2000 & Ursino, M. & $\begin{array}{l}\text { Minassian AT, Lodi CA, } \\
\text { Beydon L }\end{array}$ & & $\begin{array}{l}\text { Bouma 92, Hayashi } 79, \text { Hoffman } \\
87, \text { Marmarou } 7587, \text { Rossner } 84 \\
95, \text { Shapiro } 8083\end{array}$ & $\begin{array}{l}\text { Simplification of ' } 98 \text { model and validation against data from prospective clinical challenges } \\
\text { involving SABP and PaCO2. Six parameters are estimated to identify patient-specific models } \\
\text { (actually episode-specific). Vmca is predicted as well as ICP. }\end{array}$ \\
\hline 30 & 2000 & Ursino, M. & Lodi CA, Russo G & 48 & $\begin{array}{l}\text { Kontos } 78 \text {, Avezaat } 79 \text {, } \\
\text { Aaslid } 82 \text {, Hillen } 86\end{array}$ & $\begin{array}{l}\text { Model extends Lodi } 99 \text { \& Ursino } 97 \text { model, adding } \mathrm{CO} 2 \text { reactivity, circle of Willis, } \mathrm{CO} 2 \\
\text { interaction with AR, and microcirculation. Model validated by comparing its predictions with } \\
\text { data for } 20 \text { healthy volunteers vs. } 14 \text { patients w/ICA occlusion, both subjected to hyper- } \\
\text { ventilation challenge (CO2 down } 30 \% \text { ) and hypo-vent. (rebreathing to raise } \mathrm{CO} 2 \text { by } 30 \%) \text {. } \\
\text { Model behavior matches real world data. Perf. sens. analysis. TCD used to measure flow } \\
\text { velocity. Studied effect of contralateral stenosis to determine critical value (50\%). Reduced } \\
\text { caliber of AcoA and CcoA by } 75 \% \text {; results are asymmetric. Model demonstrates "Steal" and } \\
\text { shows poss. mechanisms. }\end{array}$ \\
\hline 31 & 2001 & Ursino, M. & Magosso E & 38 & $\begin{array}{l}\text { Kontos } 78, \text { Kiening 96, } \\
\text { Muizelaar } 8392\end{array}$ & $\begin{array}{l}\text { Adds role of O2 in CAR to previous model. Parameter estimated via best fit algorithm } \\
\text { applied progressively, first to each mechanism in isolation (hypercapnia, hypoxia, CPP } \\
\text { changes), then acting together. Also used to study hemodilution, first with ICP held constant, } \\
\text { then not. }\end{array}$ \\
\hline 32 & 2003 & Ursino, M. & Guilioni M & & $\begin{array}{l}\text { Aaslid } 82, \text { Czosnyka } 9497 \\
\text { Panerai } 98, \text { Kontos } 78, \text { Giller } \\
91\end{array}$ & $\begin{array}{l}\text { Uses a theoretical model to develop a CAR index based on pulse morphology of TCD } \\
\text { velocity waveform. Index is shown to be linear and highly sensitive to AR state and } \\
\text { insensitive to changes in other important parameters such as CSF uptake resistance and } \\
\text { intracranial elasticity. }\end{array}$ \\
\hline 33 & 1992 & $\begin{array}{l}\text { Czosnyka, } \\
\text { M. }\end{array}$ & $\begin{array}{l}\text { Pickard J, Whitehouse } \\
\text { H, Piechnik S }\end{array}$ & 15 & Giller 91 & $\begin{array}{l}\text { Hyperaemic response to reduction in CPP (measured by TCD). SA defined as State of } \\
\text { Autoregulation }(0-1) \text {. Non-invasive assessment of SA. }\end{array}$ \\
\hline 34 & 1993 & $\begin{array}{l}\text { Czosnyka, } \\
\text { M. }\end{array}$ & $\begin{array}{l}\text { Harris N, Pickard J, } \\
\text { Piechnik S }\end{array}$ & 25 & $\begin{array}{l}\text { Ursino 88, Guilioni 88, } \\
\text { Hoffman } 83\end{array}$ & $\begin{array}{l}\text { Considers pulsatility effects (vs. CPP and PaCO2) --> pulse amplitude is useful; theoretical } \\
\text { discussion only }\end{array}$ \\
\hline 35 & 1993 & $\begin{array}{l}\text { Csoznyka, } \\
\text { M. }\end{array}$ & \begin{tabular}{|} 
Piechnik S, Koszewski \\
W, Laniewski P + 5 more
\end{tabular} & & $\begin{array}{l}\text { Ekstadt } 78, \text { Gray and } \\
\text { Rossner } 87 \text {, Hoffman } 83\end{array}$ & $\begin{array}{l}\text { Uses sim. model to attempt to explain rel. between ICP, ICP-PP, CPP, and CBF in different } \\
\text { states of AR. Claims to elucidate the origin of plateau wave--Pi exceeds Ps (inversion) } \\
\text { triggers cascade. Calls into question Gray and Rossner findings on rel. of PVI to CPP. }\end{array}$ \\
\hline
\end{tabular}


Table II. Major insights and contributions of each article, grouped by research team, and sorted by when each team entered the field.

\begin{tabular}{|c|c|c|c|c|c|c|}
\hline \# & Year & $\begin{array}{l}\text { Lead } \\
\text { Author }\end{array}$ & Co-authors & \begin{tabular}{|l|l} 
\\
Cits
\end{tabular} & Other authors cited (sel.) & Major insights, contributions \\
\hline 36 & 1997 & $\begin{array}{l}\text { Czosnyka, } \\
\text { M. }\end{array}$ & $\begin{array}{l}\text { Piechnik S, Richards H, } \\
\text { Kirkpatrick P, Smielewski P, } \\
\text { Pickard J }\end{array}$ & 47 & $\begin{array}{l}\text { Portnoy } 82, \text { Ursino } 88, \text { Sorek } \\
\text { 86, Rossner } 84\end{array}$ & $\begin{array}{l}\text { Application of model to secondary insults. AR reserve to enhance interpretation of bedside } \\
\text { tests. }\end{array}$ \\
\hline 37 & 2001 & $\begin{array}{l}\text { Piechnik, } \\
\text { S.K. }\end{array}$ & $\begin{array}{l}\text { Czosnyka M, Harris NG, } \\
\text { Minhas PS, Pickard JD }\end{array}$ & & $\begin{array}{l}\text { Aaslid 89, Gao 97, Eksted } \\
77, \text { Hillen } 86, \text { Hoffman } 85,87 \\
\text { Hudetz } 8293 \text {, Ursino } 90\end{array}$ & $\begin{array}{l}\text { Modification of earlier model to study the so-called "steal" phenomenon when arterial } \\
\text { stenosis is not present (as with most TBI cases). Models extreme case to accentuate effects. } \\
\text { Findings suggest "steal" effect is not likely to occur without stenosed carotid arteries. } \\
\text { Suggests no special therapy is indicated. Proposes a non-invasive method for assessing } \\
\text { collateral flow and quantify asymmetry. }\end{array}$ \\
\hline 38 & 2001 & $\begin{array}{l}\text { Piechnik, } \\
\text { S.K. }\end{array}$ & $\begin{array}{l}\text { Czosnyka M, Richards } \\
\text { HK, Whitfield PC, } \\
\text { Pickard JD }\end{array}$ & & $\begin{array}{l}\text { Gao } 98, \text { Hoffman } 85, \text { Luca } \\
\text { 82, Marmarou } 96, \text { Ursino } \\
90,97,98, \text { Zagzoule } 86\end{array}$ & $\begin{array}{l}\text { Models cerebral venous outflow both physically and mathematically. Finds that flow does not } \\
\text { cease, even when ICP exceed ABP; rather it is reduced considerably ( } 80 \%) \text {. Suggests } \\
\text { "Starling resistor" model may not be appropriate for bridging veins; provides alternative. }\end{array}$ \\
\hline 39 & 2001 & $\begin{array}{l}\text { Piechnik, } \\
\text { S.K. }\end{array}$ & & 238 & & $\begin{array}{l}\text { Detailed review of intracranial physiology and thorough lit review of IC models. Presents } \\
\text { several models focused on different aspects of ICP and CSF dynamics. Three models are } \\
\text { published as separate papers and are reviewed elsewhere, and two additional papers are not } \\
\text { focused on modeling. Much model detail is provided. }\end{array}$ \\
\hline 40 & 1995 & Yu, J. & Lakin WD, Penar P & & none & $\begin{array}{l}\text { ICP dynamics model can be simplified by treating variables that change slowly as constants } \\
\text { over short time. This can dramatically reduce stiffness of the system and reduce numerical } \\
\text { integration issues. }\end{array}$ \\
\hline 41 & 1997 & $\begin{array}{l}\text { Kadas, } \\
\text { Z.M. }\end{array}$ & $\begin{array}{l}\text { Lakin WD, Yu J, Penar } \\
\text { PL }\end{array}$ & & $\begin{array}{l}\text { Portnoy } 82, \text { Guilioni } 88, \text { Gray } 87, \\
\text { Agarwal } 6971 \text {, Chopp } 80, \\
\text { Marmarou } 78 \text { Hakim } 76, \\
\text { Hoffman } 87, \text { Rekate } 88\end{array}$ & $\begin{array}{l}\text { Introduces AR as nonlinearity to otherwise linear 4-compartment mathematical model of } \\
\text { intracranial pressures, volumes, and flows. AR modeled as instantaneously variable } \\
\text { resistance. model. Non-constant compliance between CSF and brain. Used MAPLE to } \\
\text { solve. Logistic rather than Exponential. }\end{array}$ \\
\hline 42 & 1999 & $\begin{array}{l}\text { Lakin, } \\
\text { W.D. }\end{array}$ & Yu J, Penar PL & & $\begin{array}{l}\text { Kadas } 97, \text { Karni } 87 \\
\text { Marmarou } 75 \text {, Sorek } 88\end{array}$ & $\begin{array}{l}\text { Seven compartment model without AR but with nonlinear (logistic) CSF/brain compliance; } \\
\text { calibrated with prospective animal data---uses logistic curve, not PVI. Predicts ICP over time } \\
\text { in response to bolus injection of CSF in rabbit model. Good fit obtained. }\end{array}$ \\
\hline 43 & 2000 & $\begin{array}{l}\text { Stevens, } \\
\text { S.A. }\end{array}$ & Lakin WD & & $\begin{array}{l}\text { Chopp 80, Czosnyka 93,97, Friden 83, } \\
\text { Hakim 76, Karni 87, Marmarou } 75, \\
\text { Sorek } 88, \text { Sullivan } 85\end{array}$ & $\begin{array}{l}\text { Provides four compartment mathematical model of intracranial blood and CSF, with } \\
\text { supporting equations to reproduce highly nonlinear aggregate P-V curve. Simulated infusion } \\
\text { tests provide textbook curve nearly exactly. }\end{array}$ \\
\hline 44 & 2000 & $\begin{array}{l}\text { Stevens, } \\
\text { S.A. }\end{array}$ & & & $\begin{array}{l}\text { Karni } 87 \text {, Friden } 83 \text {, Portnoy } \\
83 \text {, Lakin } 96, \text { Albeck } 91 \\
\text { Sorek } 88\end{array}$ & $\begin{array}{l}\text { Clinical CSF infusion experiments by Albeck } 91 \text { augment mathematical analysis using seven- } \\
\text { compartment model by Karni ( } 87) \text { to deduce mean pressures not easily measured, using a } \\
\text { minimum of assumptions. Normal physiology assumed, but could be adapted for } \\
\text { pathophysiology. }\end{array}$ \\
\hline 45 & 2003 & $\begin{array}{l}\text { Lakin, } \\
\text { W.D. }\end{array}$ & $\begin{array}{l}\text { Stevens SA, Tranmer BI, } \\
\text { Penar PL }\end{array}$ & & $\begin{array}{l}\text { Hakim } 76 \text {, Chopp } 80 \\
\text { Hoffman } 87, \text { Czosnyka } \\
93,97, \text { Kadas } 97, \text { Karni } \\
\text { 86,87, Rekate } 88 \text {, Sorek } 88 \\
\end{array}$ & $\begin{array}{l}\text { Ambitious 16-compartment "whole body" mathematical model, half of which are extracranial. } \\
\text { Nonlinear equations, reduced assumptions (e.g. Monroe-Kellie not assumed). Includes } \\
\text { filtration and lymphatics in addition to direct flows. Has partial lit. review. Extensive calibration } \\
\text { at steady state provided. Many variable compliances and resistances. Validated by simulated } \\
\text { infusion tests and two catastrophic events. Also provides significant historical development } \\
\text { of predecessor models. }\end{array}$ \\
\hline 46 & 2005 & $\begin{array}{l}\text { Stevens, } \\
\text { S.A. }\end{array}$ & Lakin $\mathrm{W}$, Penar $\mathrm{P}$ & & $\begin{array}{l}\text { Friden } 83, \text { Karni } 87 \\
\text { Marmarou } 78 \text {, Sorek } 88, \\
\text { Ursino } 88\end{array}$ & $\begin{array}{l}\text { Uses simplified variant of } 2003 \text { model to study ICP in supine, head-down tilt and microgravity } \\
\text { conditions (outer space). Steady state closed form solutions are utilized. Important } \\
\text { considerations include the effects of changes in blood-brain filtration over time. Model shows } \\
\text { ICP remains normal in microgravity. }\end{array}$ \\
\hline
\end{tabular}

Page 4 of 5 
Table II. Major insights and contributions of each article, grouped by research team, and sorted by when each team entered the field.

\begin{tabular}{|c|c|c|c|c|c|c|}
\hline \# & Year & $\begin{array}{l}\text { Lead } \\
\text { Author }\end{array}$ & Co-authors & \begin{tabular}{|l|}
$\#$ \\
Cits \\
\end{tabular} & Other authors cited (sel.) & Major insights, contributions \\
\hline 47 & 2007 & $\begin{array}{l}\text { Stevens, } \\
\text { S.A. }\end{array}$ & $\begin{array}{l}\text { Previte M, Lakin W, } \\
\text { Thakore N, Penar P, } \\
\text { Hamschin B }\end{array}$ & & $\begin{array}{l}\text { Csoznyka 97, Friden } 83 \text {, } \\
\text { Karni } 87 \text {, Piechnik 01, Sorek } \\
88\end{array}$ & $\begin{array}{l}\text { Further simplified version of } 2005 \text { math. Model, applied to idiopathic intracranial } \\
\text { hypertension. Model shows multiple steady states. The nalysis may help to resolve } \\
\text { controversy re stenosis role. Thorough discussion of eqns., parameter estimation, and } \\
\text { stability/state transition analysis in terms of phase space and basins of attraction. }\end{array}$ \\
\hline 48 & 2007 & $\begin{array}{l}\text { Stevens, } \\
\text { S.A. }\end{array}$ & $\begin{array}{l}\text { Thakore N, Lakin W, } \\
\text { Penar P, Tranmer, B }\end{array}$ & & $\begin{array}{l}\text { Sorek } 88, \text { Ursino } 88, \\
\text { Csoznyka } 97, \text { Piechnik } 01 \\
\text { Marmarou } 78,\end{array}$ & $\begin{array}{l}\text { Uses } 2005 \text { model with Starling-like resistor added to show effect of non-rigid transverse sinus } \\
\text { on CSF flow/uptake. Studies IIH via analysis of steady state \& transient response. Shows } \\
\text { how two stable states can result from triggering even: } 1 \text { normal, } 1 \text { w/elevated ICP. Calibrated } \\
\text { to } 3 \text { specific subjects w/perfect fit. }\end{array}$ \\
\hline 49 & 1996 & Bekker, A. & $\begin{array}{l}\text { Wolk S, Turndorf H, } \\
\text { Kristol D, Ritter A }\end{array}$ & & $\begin{array}{l}\text { Sorek 89, Ursino } 889091 \\
\text { Paulsen } 90, \text { Harper } 85 \\
\text { Marmarou } 78\end{array}$ & $\begin{array}{l}\text { PK interaction plus } \mathrm{P} \text { and } \mathrm{V} \text { to achieve a systematic examination. Uses graphical functions } \\
\text { for conductance vs. MAP (artery to arteriole). Goal is reduction of elevated ICP induced by } \\
\text { surgical procedures. }\end{array}$ \\
\hline 50 & 1999 & Bekker, A. & $\begin{array}{l}\text { Mustry A, Ritter AA, } \\
\text { Wolk SC, Turndorf H }\end{array}$ & 33 & Ursino 90 91, Aaslid 89 & $\begin{array}{l}\text { Combines P-K model with model of cerebrovascular dynamics, to study ICP during } \\
\text { anesthesia and laryngoscopy under conditions of AR and no-AR. Model results match } \\
\text { clinical data from several studies to varying degrees. }\end{array}$ \\
\hline 51 & 1997 & Gao, E. & $\begin{array}{l}\text { Young W, Ornstein E, } \\
\text { Pile-Spellman E, Ma Q }\end{array}$ & 47 & Foggarty-Mack 96 & $\begin{array}{l}\text { Models vasculature more fully than other models, with a focus on AVM shunts and } \\
\text { associated surgical procedures. }\end{array}$ \\
\hline 52 & 1998 & Gao, E. & $\begin{array}{l}\text { Young W, Pile-Spellman } \\
\text { E, Ornstein E, Ma Q }\end{array}$ & 44 & Kontos 78 & $\begin{array}{l}\text { Reports improved AR formula vs. those frequently used, based on } 4 \text { compartment ( } 288 \\
\text { vessel) model of arteries and arterioles. Effective resistance as a fn. of pressure, } \\
\text { instantaneous formula }\end{array}$ \\
\hline 53 & 1998 & $\begin{array}{l}\text { Bergsneid } \\
\text { er, M. }\end{array}$ & $\begin{array}{l}\text { Alwan A, Falkson L, } \\
\text { Rubinstein E }\end{array}$ & & $\begin{array}{l}\text { Avezaat 79, Marmarou 78, } \\
\text { Ursino } 88\end{array}$ & $\begin{array}{l}\text { Elevated ICP is a response to reduced CBF not the cause of reduced CBF, often due to } \\
\text { interference in pulsatile CSF movement that increases venous pulsatility... which reduces } \\
\text { flow. }\end{array}$ \\
\hline 54 & 1998 & $\begin{array}{l}\text { Thoman, } \\
\text { W.J. }\end{array}$ & $\begin{array}{l}\text { Lampotang S, } \\
\text { Gravenstein D, Aa J }\end{array}$ & & Leenders 90 & $\begin{array}{l}\text { Intracranial dynamic model linked to patient simulator. Used for teaching clinicians, } \\
\text { especially anesthesiologists, about complex intracranial interactions. Achieves purpose even } \\
\text { though modeling approach is at variance with the bulk of intracranial modeling literature. }\end{array}$ \\
\hline 55 & 1999 & $\begin{array}{l}\text { Thoman, } \\
\text { W.J. }\end{array}$ & $\begin{array}{l}\text { Gravenstein D, Aa J, } \\
\text { Lampotang S }\end{array}$ & 21 & $\begin{array}{l}\text { Michenfelder 88, Leenders } \\
90, \text { Ursino } 8891\end{array}$ & $\begin{array}{l}\text { Extended } 1998 \text { work adding cerebro intracranial dynamic model to patient simulator to now } \\
\text { include AR, and further validated model against published "curves." }\end{array}$ \\
\hline 56 & 2003 & Cirovic, S. & Walsh C, Fraser W & 50 & $\begin{array}{l}\text { Chopp 83, Portnoy 94, } \\
\text { Sorek, Ursino }\end{array}$ & $\begin{array}{l}\text { Volume-Pressure test: full range of Pcsf change. No capillarial compartment; splits venous } \\
\text { into } 2 \text { compartments. Clear derivation. Reproduces Chopp results more completely. Auto } \\
\text { regulation does not have a dominant effect. }\end{array}$ \\
\hline 57 & 2005 & $\begin{array}{l}\text { Wakeland, } \\
\text { W. }\end{array}$ & Goldstein B & & $\begin{array}{l}\text { Csoznyka 97,Lakin 03, } \\
\text { Marmarou 78, Ursino 97, } 01\end{array}$ & $\begin{array}{l}\text { An ICP dynamic model that treats the various intracranial volumes as the state variables } \\
\text { instead of the pressures. Uses a non-standard approach to model the AR limits. Diagram \& } \\
\text { flow logic are more approachable for clinicians. }\end{array}$ \\
\hline 58 & 2006 & Gaohua, L. & Kimura $\mathrm{H}$ & 52 & $\begin{array}{l}\text { Lakin 03, Marmarou } 7578 \\
\text { Ursino } 9700\end{array}$ & $\begin{array}{l}\text { Ambitious whole body 13-compartment model focused on the reduction of elevated ICP via } \\
\text { hypothermia. Full hydrodynamic model + biothermal model. Details of equations and } \\
\text { parameters provided. Some model validation tests performed. Features use of a [PID] control } \\
\text { circuit to maintain a target ICP of simulated patient. }\end{array}$ \\
\hline 59 & 2007 & $\mathrm{Hu}, \mathrm{X}$. & $\begin{array}{l}\text { Nenov V, Bergsneider M, } \\
\text { Glenn T, Vespa P, Martin } \\
\text { N }\end{array}$ & & $\begin{array}{l}\text { Takame 87, Sorek } 89, \\
\text { Csnoznyka } 97 \text {, Ursino } 8891 \\
959798 \text { 03, Lodi } 98, \text { Aaslid } \\
89, \text { Kontos } 78 \text {, Friden } 94\end{array}$ & $\begin{array}{l}\text { Ambitious synthesis of simulation, parameter identification, and nonlinear Kalman filters (KF) } \\
\text { to accomplish model-based intracranial state estimation. Uses Ursino } 88 \text { ICP dynamic model } \\
\text { w/simplications from } 97 \text { model. Reviews physiology and provides many model details, incl. } \\
\text { analysis of feedback loops. Offline nonlinear optimization to id. initial parameter values. KF } \\
\text { state estimation then reduces fit error (profoundly). }\end{array}$ \\
\hline
\end{tabular}

Page 5 of 5 
Table III: Focus of model, phenomena studied, and data provided

\begin{tabular}{|c|c|c|c|c|c|c|c|c|c|c|c|c|c|c|c|c|c|c|c|c|c|c|c|c|c|c|c|c|c|c|c|c|c|c|c|c|c|}
\hline & & & & & & & & $\mathrm{cus}$ & of & $\overline{\mathrm{Mc}}$ & & & & & & & & & he & 10r & en & in & $\overline{\mathrm{ves}}$ & tiga & $\overline{t e d}$ & $\bar{A}$ & $p p$ & ica & tion & & & $\mathrm{n} . / 1$ & Exp & . Da & ata & Pro & ovid \\
\hline \# & 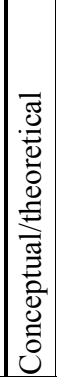 & 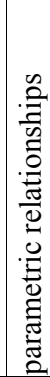 & 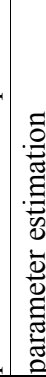 & 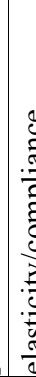 & 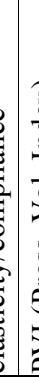 & 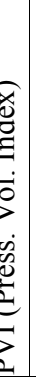 & 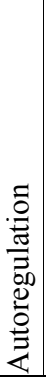 & 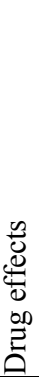 & 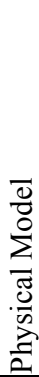 & 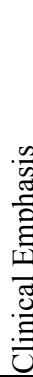 & .0̃ & 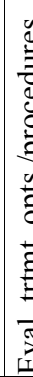 & & & 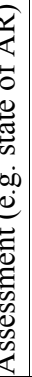 & 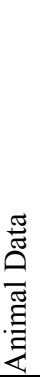 & 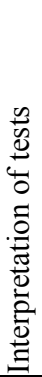 & 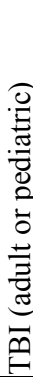 & 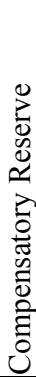 & 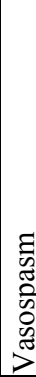 & 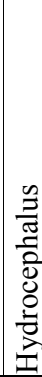 & 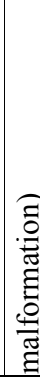 & 丞 & 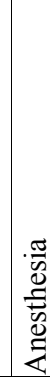 & 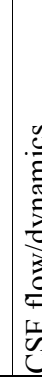 & & & 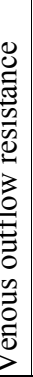 & 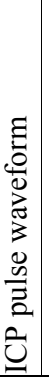 & $\begin{array}{l}3 \\
0 \\
0 \\
0 \\
0 \\
0 \\
\frac{0}{0} \\
\bar{\pi} \\
\frac{0}{0} \\
0 \\
0 \\
0\end{array}$ & & 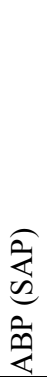 & & 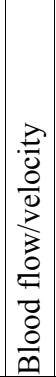 & 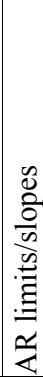 & & 5 \\
\hline 11 & $\mathrm{X}$ & $\bar{X}$ & $\overline{\mathrm{X}}$ & $\bar{x}$ & & $\overline{\mathrm{X}}$ & & & & & 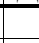 & 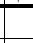 & 7 & & & $\bar{X}$ & & & & $\bar{X}$ & & & & & $\bar{X}$ & & & $\bar{X}$ & & & $\bar{X}$ & 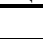 & & & & & $\mathrm{X}$ \\
\hline 2 & $X$ & $\mathrm{X}$ & $\mathrm{X}$ & $\bar{X}$ & & X & & & & & & & & & & $\mathrm{X}$ & $\mathrm{X}$ & & & & & & & & $X$ & & V & $\mathrm{X}$ & & & $\mathrm{X}$ & & & & & $\mathrm{X}$ & $\mathrm{X}$ \\
\hline 3 & & $\mathrm{X}$ & $\underline{X}$ & $X$ & & & & & $\mathrm{X}$ & & & $X$ & & & $\bar{X}$ & & & & & & $\mathrm{X}$ & & & & $X$ & & & & & & & & & & & & \\
\hline 4 & $X$ & $\mathrm{X}$ & & $X$ & & $X$ & & & & & & & & & & & & & & & & & & & & & & $\underline{X}$ & & & & & & & & & \\
\hline 5 & $\mathrm{X}$ & & & & & & & & & & & & & & & $X$ & & & & & & & & & $X$ & & & & & & $\mathrm{X}$ & & & & & & \\
\hline 6 & $X$ & & & & & & $\mathrm{X}$ & & & & & & & & & & & & & & & & & & & & & & & & & & & $\mathrm{X}$ & & & \\
\hline 7 & & $\mathrm{X}$ & & $x$ & & $\bar{X}$ & $\mathrm{X}$ & & & & & & & & & & & & & & $\mathrm{X}$ & & & & $\bar{X}$ & & & $\bar{X}$ & & & & & & & & & \\
\hline 8 & $X$ & $\mathrm{X}$ & $\mathrm{X}$ & $\bar{X}$ & & $\bar{X}$ & $\mathrm{X}$ & & & & & & & & & $X$ & & $X$ & & & & & & & $X$ & & X & & & & & & & $\mathrm{X}$ & & & \\
\hline 9 & & $\mathrm{X}$ & $\mathrm{X}$ & $X$ & & & & & & & & & & & & $\bar{X}$ & & & & & & & & & $X$ & & & & & & & $\mathrm{X}$ & & & & & \\
\hline 10 & & $\mathrm{X}$ & $\mathrm{X}$ & & & & & & & & & & & & & & 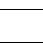 & & & & $X$ & & & & X & & & & & & & & & 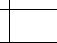 & & & \\
\hline 11 & & & & $\bar{X}$ & & & & & & & 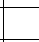 & 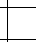 & & & $\bar{X}$ & 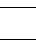 & 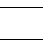 & 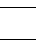 & & & & & & & & & X & & $X$ & & & 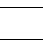 & & 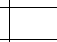 & & & \\
\hline 12 & $X$ & & & & & & 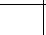 & & & & & $y$ & & & & & & & & & $\mathrm{X}$ & & & & $X$ & & & & & & & 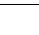 & & 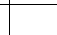 & & & \\
\hline 13 & & & & & & & & & & & $X$ & $x$ & & & & $\mathrm{X}$ & 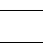 & 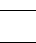 & & & $\mathrm{X}$ & & & & 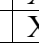 & & & & & & & 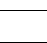 & & 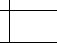 & & & \\
\hline 14 & & $\mathrm{X}$ & $\mathrm{X}$ & $X$ & & & $\mathrm{X}$ & & & & & & & & & & & & & & & & & & X & & $\bar{X}$ & & $\mathrm{X}$ & & & $L$ & & & & & \\
\hline 15 & & $\mathrm{X}$ & $\mathrm{X}$ & $X$ & & & $\mathrm{X}$ & & & & & & & & & & $X$ & & & & & & & & $\bar{X}$ & & & & $X$ & & & 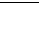 & & 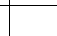 & & & \\
\hline 16 & & & & & & & & & & & & & & & $\mathrm{X}$ & & & & & & & & & & & & & & $\mathrm{X}$ & & & & & 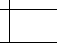 & & & \\
\hline 17 & & $\mathrm{X}$ & $\mathrm{X}$ & $X$ & & & $\mathrm{X}$ & & & & & & & & & & 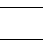 & & & & & & & & $\square$ & & $\bar{I}$ & & & & & & & & & & \\
\hline 18 & & & & & & & $\mathrm{X}$ & & & & & & 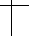 & & & & 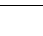 & & & & & & & & & & & & & $\mathrm{X}$ & & 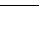 & & $\mathrm{X}$ & & & \\
\hline 19 & $X$ & & & & & & $\mathrm{X}$ & & & & & & & & & & & & $X$ & & & & & & $X$ & & X & & & $\begin{array}{l}x \\
X \\
\end{array}$ & & & & $\mathrm{X}$ & & & \\
\hline 20 & $\mathrm{X}$ & & $\mathrm{X}$ & $X$ & & $\bar{X}$ & $\mathrm{X}$ & & & $\mathrm{X}$ & & & & & $\bar{X}$ & & $\mathrm{X}$ & $\mathrm{X}$ & $\mathrm{X}$ & & & & & & X & & & $\bar{X}$ & & & $\mathrm{X}$ & $\mathrm{X}$ & & $\mathrm{X}$ & & & \\
\hline 211 & $X$ & $\mathrm{X}$ & $\mathrm{X}$ & $x$ & & & $\mathrm{X}$ & & & $\mathrm{X}$ & & $X$ & & & $\bar{X}$ & & $\mathrm{X}$ & $\underline{X}$ & $\mathrm{X}$ & & & & & $\mathrm{X}$ & & & & $\bar{X}$ & & & & & & $\mu$ & $\mathrm{X}$ & & \\
\hline 22 & $X$ & & & $X$ & & $\mathrm{X}$ & $\mathrm{X}$ & & & & & & & & $\mathrm{X}$ & & $\mathrm{X}$ & $\mathrm{X}$ & $\mathrm{X}$ & & & & & & $\lambda$ & & X & $\mathrm{X}$ & & & & 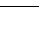 & & 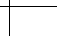 & & & \\
\hline 23 & $X$ & & $X$ & & & & $\mathrm{X}$ & & & $\mathrm{X}$ & & & & & $\frac{\hat{x}}{\mathrm{X}}$ & & $\mathrm{X}$ & $\mathrm{X}$ & $\mathrm{X}$ & & & & & & $\frac{x}{X}$ & & X & X & & & $\mathrm{X}$ & $\mathrm{X}$ & & & & & $\mathrm{X}$ \\
\hline 24 & $X$ & $\mathrm{X}$ & $\mathrm{X}$ & $x$ & & & $\mathrm{X}$ & & & & & $x$ & & & & & $\mathrm{X}$ & $\mathrm{X}$ & $\mathrm{X}$ & & & & & & & & & & & & $\mathrm{X}$ & $\mathrm{X}$ & $X$ & X & & & \\
\hline 24 & $X$ & $\mathrm{X}$ & & $x$ & & & $\mathrm{X}$ & & & & & & & & $\mathrm{X}$ & & $\mathrm{X}$ & $\mathrm{X}$ & $X$ & & & & & & & & X & & & & & & & & & & \\
\hline 25 & $X$ & $\mathrm{X}$ & & $\bar{X}$ & & & $\mathrm{X}$ & & & $\mathrm{X}$ & & $X$ & & & $\bar{X}$ & & $\mathrm{X}$ & $\mathrm{X}$ & $X$ & & & & & & 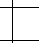 & & & & & & $\mathrm{X}$ & $\mathrm{X}$ & $\mathrm{X}$ & $\mathrm{X}$ & & & \\
\hline 27 & $\mathrm{X}$ & $\mathrm{X}$ & $\mathrm{X}$ & & & & $\mathrm{X}$ & & & & & & & & $\bar{X}$ & & $\mathrm{X}$ & $\mathrm{X}$ & $\mathrm{X}$ & $X$ & & & & & & & & & & & & & & $\mathrm{X}$ & & & \\
\hline 28 & & & & & & & & & & & & & & & & & $\mathrm{X}$ & & & & & & $\mathrm{X}$ & & & & & & & & & & $\mathrm{X}$ & $\mathrm{X}$ & & & \\
\hline 29 & $x$ & & $\mathrm{X}$ & & & & $\mathrm{X}$ & & & $\mathrm{X}$ & & & & & $\mathrm{X}$ & & $\mathrm{X}$ & $\mathrm{X}$ & $X$ & & & & & & 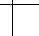 & & $\bar{X}$ & & & & $\mathrm{X}$ & $\mathrm{X}$ & $\mathrm{X}$ & $\mathrm{X}$ & & & \\
\hline 30 & & & & & & & $\mathrm{X}$ & & & $X$ & & & & & & & $\mathrm{X}$ & & $X$ & & & $X$ & $X$ & & & & & & & & & & $\mathrm{X}$ & $\mathrm{X}$ & & & \\
\hline 31 & X & $\mathrm{X}$ & $X$ & & & & $\mathrm{X}$ & & & & $\mathrm{X}$ & & & & $\bar{X}$ & $\mathrm{X}$ & & & $\mathrm{X}$ & & & & & & 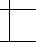 & & & & & & $\mathrm{X}$ & & $\mathrm{X}$ & $\mathrm{X}$ & $\mathrm{X}$ & & \\
\hline 32 & $\mathrm{X}$ & $X$ & & $x$ & & & $\mathrm{X}$ & & & & & & & & $\mathrm{X}$ & & & $\mathrm{X}$ & $\mathrm{X}$ & & & & & & & & & & & & & & & & & & \\
\hline 33 & & & $X$ & - & & & $\mathrm{X}$ & & & & & & & & $\mathrm{X}$ & & & & $\mathrm{X}$ & & & & & & & & & & & & & & & $\mathrm{X}$ & & & \\
\hline 34 & $X$ & & & & & & $\mathrm{X}$ & & & & & & & & $\bar{X}$ & & & & $\mathrm{X}$ & & & & & & & & $\bar{X}$ & & & & & & & & & & \\
\hline 35 & & $\mathrm{X}$ & & $x$ & & $\mathrm{X}$ & $\mathrm{X}$ & & & & & & & & & $\mathrm{X}$ & & & $\mathrm{X}$ & & & & & & $X$ & & & $\bar{X}$ & & & $\mathrm{X}$ & & & $\mathrm{X}$ & & & \\
\hline 36 & & & & & & & $\mathrm{X}$ & & & $\mathrm{X}$ & & & & & $\mathrm{X}$ & & $\mathrm{X}$ & $\mathrm{X}$ & $\mathrm{X}$ & & & & & & & & & & & & $\mathrm{X}$ & $\mathrm{X}$ & & $\mathrm{X}$ & & & \\
\hline 37 & $\mathrm{X}$ & & & & & & $\mathrm{X}$ & & & & & & & & $\bar{X}$ & & & $\mathrm{X}$ & $\mathrm{X}$ & & & & $\mathrm{X}$ & & & & & & & & & & & & & & \\
\hline 38 & $X$ & $\mathrm{X}$ & & & & & & & $\mathrm{X}$ & & & & & & & & & & & & & & & & & & & $\bar{X}$ & & & & & & & & & \\
\hline 39 & & $\mathrm{X}$ & $\mathrm{X}$ & $x$ & & & $\mathrm{X}$ & & & & $\mathrm{X}$ & & & & $\mathrm{X}$ & $\mathrm{X}$ & $X$ & $X$ & $X$ & $X$ & & $\mathrm{X}$ & $X$ & & $\bar{X}$ & & $\bar{X}$ & $\mathrm{X}$ & & & $X$ & $\mathrm{X}$ & & $\mathrm{X}$ & $X$ & & \\
\hline 40 & $x$ & & & & & & & & & & & & & & & & & & & & & & & & & & & & & & & & & & & & \\
\hline 41 & $\mathrm{X}$ & $X$ & & & & & $\mathrm{X}$ & & & & & & & & & & & & & & & & & & & & & & & & & & & & & & \\
\hline 42 & $X$ & $\mathrm{X}$ & $\mathrm{X}$ & $X$ & & $\bar{X}$ & & & & & & & & & & $\mathrm{X}$ & & & & & & & & & & & & & & & $\mathrm{X}$ & & & & & & \\
\hline 43 & & & & 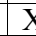 & & & & & & & & & & & & & & & & & & & & & $X$ & & & & & & & & & & & & \\
\hline 44 & & & $\mathrm{X}$ & & & & & & & & & & & & & & & & & & & & & & $X$ & & & $\bar{X}$ & & & & & & & & & \\
\hline 45 & $x$ & $\mathrm{X}$ & $\mathrm{X}$ & $X$ & & $X$ & $X$ & & & & & & & & & & & & & & & & & & X & & & & & & & & & & & & \\
\hline 46 & $X$ & $\mathrm{X}$ & $\mathrm{X}$ & & & & & & & & $\underline{X}$ & & & & & & & & & & & & & & $X$ & & & $\bar{X}$ & & & $\mathrm{X}$ & & & & & & \\
\hline 47 & $\mathrm{X}$ & $X$ & $\mathrm{X}$ & $X$ & & & & $\mathrm{X}$ & & & & $X$ & & & & & & & & & & & & & $\bar{X}$ & & & & & & & & & & & & \\
\hline 48 & $X$ & & $\mathrm{X}$ & $\bar{X}$ & & & & & & & & & & & & & & & & & & & & & 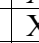 & & & & & & & & & & & & \\
\hline 49 & $\mid x$ & $\mathrm{X}$ & & & & & $\mathrm{X}$ & $\mathrm{X}$ & & & & $\bar{X}$ & & & & & & & & & & & & $\mathrm{X}$ & & & & & & & & & & & & & \\
\hline 50 & & $\mathrm{X}$ & & & & & & X & & & & $x$ & & & & & & & & & & & & $\mathrm{X}$ & & & & & & & & & & & & & \\
\hline 51 & & & & $x$ & & & $\mathrm{X}$ & $\mathrm{X}$ & & & & & & & $\bar{X}$ & & & & & & & & & $\mathrm{X}$ & & & & & & & $\mathrm{X}$ & & & & & & \\
\hline 52 & $X$ & & & & & & & & & & & $\bar{X}$ & & & & & & & & & & $\mathrm{X}$ & & & & & & & & & & $\mathrm{X}$ & & $\mathrm{X}$ & & & \\
\hline 53 & $X$ & $\mathrm{X}$ & $X$ & & & & $\mathrm{X}$ & & & & & & & & & & & & & & & & & & & & & & & & & & & & $X$ & & \\
\hline 54 & $X$ & & & $\lambda$ & & & & & & & & & & & & & & & & & & & & & $\underline{X}$ & & & & & & & & & & & & \\
\hline 55 & & $\bar{X}$ & & & & & $\mathrm{X}$ & $\mathrm{X}$ & & & & I & & & & & & & & & & & & $\mathrm{X}$ & & & & & & & & & & & & & \\
\hline 56 & $X$ & $\mathrm{X}$ & & & & & & & & & & & & & & & & & & & & & & & & & & X & & & & & & & & & \\
\hline 57 & $x$ & & & & & & $X$ & & & & & & & & & & & & & & & & & & $\mathrm{X}$ & & & & & X & X & & & & & & \\
\hline 58 & $X$ & $\mathrm{X}$ & $\mathrm{X}$ & & & & & & & & & X & & & & & & & & & & & & & & & & & & & & & & & & & \\
\hline 59 & $\mathrm{X}$ & $X$ & & & & & & X & & & & & & & & & & $\mathrm{X}$ & & & & & & & & & & & & & & & & $X$ & & & \\
\hline
\end{tabular}


Table IV: Model Details

\begin{tabular}{|c|c|c|c|c|c|c|c|c|c|c|c|c|c|c|c|c|c|c|c|c|c|c|c|c|c|c|c|c|c|c|c|c|c|c|c|c|c|}
\hline & & & & $\overline{\mathrm{de}}$ & $\bar{D}$ & $\overline{a g r}$ & & & & & $\overrightarrow{\mathrm{ev}}$ & aria & ble & & & & Time & & ndwi & & & & & & lel & $\overline{\mathrm{AsS}}$ & $\mathrm{uml}$ & tion & $\mathrm{ns} / \mathrm{L}$ & $\overline{\log }$ & $\mathrm{ic/} / \mathrm{s}$ & $\overline{\text { Cons }}$ & istra & & & & \\
\hline \# & 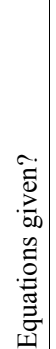 & 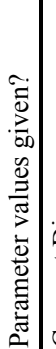 & 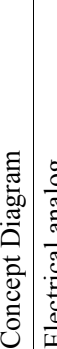 & 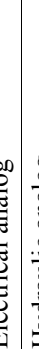 & 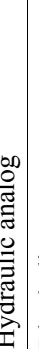 & 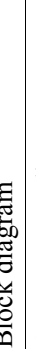 & 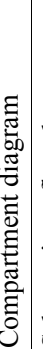 & & 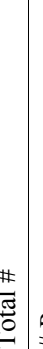 & 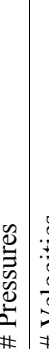 & 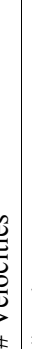 & & : & 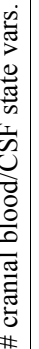 & & 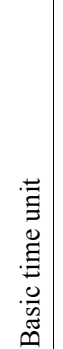 & 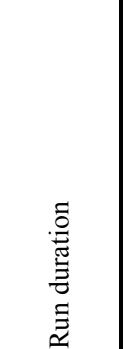 & $\begin{array}{l}\sum_{\Sigma}^{ \pm} \\
\sum^{ \pm}\end{array}$ & 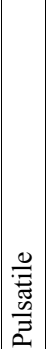 & & 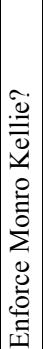 & 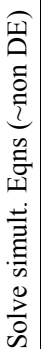 & 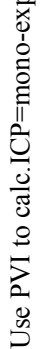 & 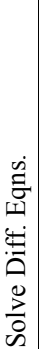 & 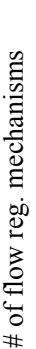 & 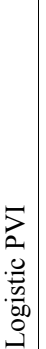 & 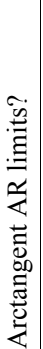 & 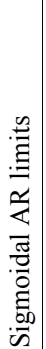 & 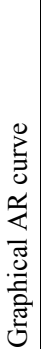 & 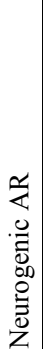 & 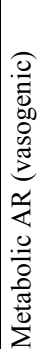 & 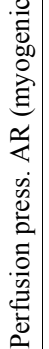 & 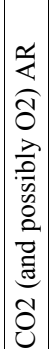 & 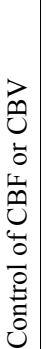 & 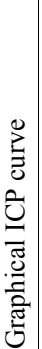 & 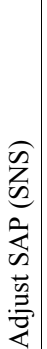 & 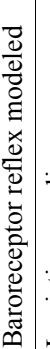 \\
\hline 1 & $\mathrm{X}$ & $\mathrm{X}$ & \begin{tabular}{l|l|}
$\mathrm{X}$ & $\bar{X}$ \\
\end{tabular} & $\mathrm{X}$ & & & & 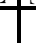 & 1 & 1 & & & & 1 & & $\min$ & 8 & $\mathrm{X}$ & & & & & $X$ & $\bar{X}$ & & & & & & & & & & & & & \\
\hline 2 & $\mathrm{X}$ & $\mathrm{x}$ & $X$ & $\mathrm{X}$ & & & & & 1 & 1 & & & & 1 & & $\min$ & 8 & $\mathrm{X}$ & & & & & $\mathrm{X}$ & $\mathrm{X}$ & & & & & & & & & & & & & \\
\hline 3 & $\mathrm{X}$ & $\mathrm{X}$ & $\mathrm{X}$ & & $\mathrm{X}$ & & & & & & & & & & & & & & & & & & & & & & & & & & & & & & & & \\
\hline 4 & $\mathrm{X}$ & & $x$ & $\mathrm{x}$ & $\mathrm{X}$ & & & & 1 & 1 & & & & 1 & & & & $\mathrm{X}$ & & & -- & $\mathrm{N}$ & $\mathrm{N}$ & & & & & & & & & & & & & & \\
\hline 5 & $\mathrm{X}$ & $\mathrm{X}$ & & & & & & & 1 & & & 1 & & & & $\min$ & 5 & $\mathrm{X}$ & & & & & & $\mathrm{X}$ & & & & & & & & & & & & & \\
\hline 6 & $\mathrm{X}$ & $\mathrm{X}$ & & & & $\mathrm{X}$ & & & 68 & & 4 & 4 & 34 & 34 & & $\mathrm{sec}$ & 2 & $\mathrm{X}$ & $\mathrm{X}$ & & & $\mathrm{X}$ & & & & & & & & & & & & & & & \\
\hline 7 & $\mathrm{X}$ & $\sim$ & $X$ & $\mathrm{X}$ & & $\mathrm{X}$ & & & 2 & 2 & & & 2 & 2 & 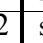 & $\mathrm{sec}$ & $80-800$ & $\mathrm{X}$ & $\mathrm{X}$ & & & & $\mathrm{X}$ & $\mathrm{X}$ & 2 & & & & & & & & & & & & \\
\hline 8 & $\mathrm{X}$ & $\mathrm{X}$ & $\mathrm{X}$ & & $\bar{X}$ & $\mathrm{X}$ & & & 8 & 4 & & 4 & 4 & 6 & 2 & $\min$ & $1-5 \mathrm{~min}$ & $\mathrm{X}$ & $\mathrm{X}$ & & $\mathrm{X}$ & & $\sim$ & $\mathrm{X}$ & 2 & & & & $\mathrm{X}$ & & & $\mathrm{X}$ & & & & $\mathrm{X}$ & $\mathrm{X}$ \\
\hline 9 & $\mathrm{X}$ & $\mathrm{X}$ & & & & & $\mathrm{X}$ & & 6 & 6 & & & 7 & 6 & & $\mathrm{sec}$ & 16 & $\mathrm{X}$ & & & $\mathrm{X}$ & $\mathrm{X}$ & $\mathrm{N}$ & & $\mathrm{n} /$ & & & & & & & & & & & & \\
\hline 10 & $\mathrm{X}$ & & & & & & $\mathrm{X}$ & & $\mathrm{K}$ & & & & & & & & & & & & & & & & & & & & & & & & & & & & \\
\hline 11 & $\mathrm{X}$ & $\mathrm{X}$ & \begin{tabular}{l|l}
$\mathrm{X}$ & $\mathrm{X}$ \\
\end{tabular} & $\mathrm{X}$ & & & & & 4 & 4 & & & & 4 & & sec & 2 & $\mathrm{X}$ & $\mathrm{X}$ & & $\mathrm{N}$ & & & & 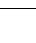 & & & & & & & & & & & & \\
\hline 12 & $\mathrm{X}$ & $\mathrm{X}$ & $X$ & & & & $\bar{X}$ & & 6 & & & 6 & 7 & 6 & & days & 2 & $\mathrm{X}$ & & & $\mathrm{X}$ & & $\mathrm{X}$ & $\mathrm{X}$ & & & & & & & & & & & & & \\
\hline 13 & (see & abo & & & & & & & & & & & & & & & & & & & & & & & & & & & & & & & & & & & \\
\hline 14 & $\mathrm{X}$ & $\mathrm{X} \mid$ & \begin{tabular}{l|l|l}
$X$ & $X$
\end{tabular} & $\mathrm{X}$ & & & & & 4 & 3 & & & & 3 & 1 & $\mathrm{sec}$ & 2 & $\mathrm{X}$ & $\mathrm{X}$ & & $\mathrm{Y}$ & & $\mathrm{N}$ & $\mathrm{X}$ & 1 & & $\mathrm{X}$ & & & & & $\mathrm{X}$ & & & $\mathrm{X}$ & & \\
\hline 15 & & & & & & & & & & & & & & & & $\mathrm{sec}$ & 2 & $\mathrm{X}$ & X & & $\mathrm{Y}$ & & $\mathrm{N}$ & $\mathrm{X}$ & 1 & & $\mathrm{X}$ & & & & & $\mathrm{X}$ & & & $\mathrm{X}$ & & \\
\hline 16 & $\mathrm{X}$ & $\mathrm{X}$ & & & & $\mathrm{X}$ & & & 4 & 3 & & & & 3 & 1 & $\mathrm{sec}$ & 4 & $\mathrm{X}$ & $\mathrm{X}$ & & $\mathrm{X}$ & & $\mathrm{N}$ & $\mathrm{X}$ & -- & & $\mathrm{X}$ & & & & & $\mathrm{X}$ & & & $\mathrm{X}$ & & \\
\hline 17 & $\mathrm{X}$ & $\mathrm{X}$ & $X$ & $\mathrm{X}$ & & & & & 5 & 5 & & & & 5 & & $\mathrm{sec}$ & $300-3000$ & $\mathrm{X}$ & & & $?$ & $\mathrm{~N}$ & $\mathrm{~N}$ & $\mathrm{X}$ & 2 & & $\mathrm{X}$ & & & $\mathrm{X}$ & & $\mathrm{X}$ & & & & & \\
\hline 18 & $\mathrm{X}$ & $\mathrm{X}$ & & & & $\bar{X}$ & & & 5 & 5 & & & & 5 & & sec & \begin{tabular}{c|c|}
$150-400$ \\
\end{tabular} & $\mathrm{X}$ & & & $\mathrm{N}$ & $\mathrm{N}$ & $\mathrm{N}$ & $\mathrm{X}$ & 5 & & $\mathrm{X}$ & & & $\mathrm{X}$ & $\mathrm{X}$ & $\mathrm{X}$ & & & & & \\
\hline 19 & & & & & & $\bar{X}$ & & & 5 & 5 & & & & 5 & & $\mathrm{sec} /$ & $60-600$ & $\mathrm{X}$ & & & $\mathrm{N}$ & $\mathrm{N}$ & $\mathrm{N}$ & $\mathrm{X}$ & 5 & & $\mathrm{X}$ & & & $\mathrm{X}$ & $\mathrm{X}$ & $\mathrm{X}$ & & & & & \\
\hline 20 & $\mathrm{X}$ & $\mathrm{X}$ & $X$ & $\mathrm{X}$ & & & & & 7 & 3 & & 2 & & 5 & 2 & $\mathrm{sec}$ & $150-750$ & $\mathrm{X}$ & $\sim$ & & $\mathrm{Y}$ & & $\mathrm{N}$ & $\mathrm{X}$ & 2 & & $\mathrm{X}$ & & & & $\mathrm{X}$ & $\mathrm{X}$ & & & & & \\
\hline 21 & $\mathrm{X}$ & $\mathrm{x}$ & & & & & & & & & & & & & & sec & $15 \mathrm{~min}$ & $\mathrm{X}$ & X & & $\mathrm{X}$ & & $\mathrm{X}$ & $\mathrm{X}$ & 2 & & & & & & $\mathrm{X}$ & $\mathrm{X}$ & & & & & \\
\hline 22 & & & \begin{tabular}{l|l}
$X$ & $X$ \\
\end{tabular} & $\mathrm{X}$ & $\mathrm{X}$ & & & & 2 & 1 & & & & 1 & & sec & $150-300$ & $\mathrm{X}$ & & & $\mathrm{Y}$ & & $\mathrm{Y}$ & $\mathrm{X}$ & 1 & & & $\mathrm{X}$ & & & $\mathrm{X}$ & & & & & & \\
\hline 23 & & & & & & 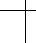 & & & 2 & 1 & & & & 1 & 1 & $\mathrm{sec}$ & $150-400$ & $\mathrm{X}$ & & & $\mathrm{Y}$ & & $\mathrm{Y}$ & $\mathrm{X}$ & 1 & & & $\mathrm{X}$ & & & $\mathrm{X}$ & & & & & & \\
\hline 24 & & $\mathrm{X}$ & $\mathrm{X}$ & & & & & & & & & & & & & $\min$ & $20-90$ & $\mathrm{X}$ & & & & & & & 3 & & & & & & $\mathrm{X}$ & $\mathrm{X}$ & $\mathrm{X}$ & & & & \\
\hline 24 & & & $\bar{X}$ & & & $\mathrm{X}$ & & & & & & & & & & & & $\mathrm{X}$ & $\mathrm{X}$ & $\mathrm{X}$ & & & & $\mathrm{X}$ & & & & & & & & & & & & & \\
\hline 25 & $\mathrm{X}$ & $\mathrm{x}$ & $X$ & $\mathrm{X}$ & & & & & 10 & 4 & & 2 & & 6 & 4 & $\mathrm{sec}$ & $50-60$ & $\mathrm{X}$ & & & $\mathrm{Y}$ & & $\mathrm{N}$ & $\mathrm{Y}$ & 2 & & & $\mathrm{X}$ & & & $\mathrm{X}$ & $\mathrm{X}$ & & & & & \\
\hline 27 & $\mathrm{X}$ & $\mathrm{X}$ & $\mathrm{X}$ & & $\mathrm{X}$ & & & & 6 & 2 & & 2 & & 4 & & & & $\mathrm{X}$ & & & & & $\mathrm{X}$ & $\mathrm{X}$ & 1 & & & $\mathrm{X}$ & & & $\mathrm{X}$ & & & & & & \\
\hline 28 & & & $\mathrm{X}$ & & $\mathrm{X}$ & & & & 0 & & & & & & & & & & & & & & & & & & & & & & & & & & & & \\
\hline 29 & $\mathrm{X}$ & $\mathrm{X}$ & & & $\mathrm{X}$ & $\mathrm{X}$ & & & 6 & 2 & & 2 & & 4 & 2 & sec & $30-50$ & $\mathrm{X}$ & & & $\mathrm{Y}$ & & $\mathrm{N}$ & $\mathrm{Y}$ & 2 & & & $\mathrm{X}$ & & & $\mathrm{X}$ & $\mathrm{X}$ & & & & & \\
\hline 30 & & $\sim$ & & & $\mathrm{X}$ & & & & 12 & & & & & & & $\mathrm{sec}$ & 150 & $\mathrm{X}$ & & & $\mathrm{Y}$ & & $\mathrm{N}$ & $\mathrm{Y}$ & 2 & & & & & & & $\mathrm{X}$ & $X$ & & & & \\
\hline 31 & $\sim$ & $\sim$ & & & & $\bar{X}$ & & & & & & & & & & $\mathrm{sec}$ & $2000+$ & $\mathrm{X}$ & & & $\mathrm{Y}$ & & $\mathrm{N}$ & $\mathrm{Y}$ & 4 & & & $\mathrm{X}$ & & & $\mathrm{X}$ & $\mathrm{X}$ & X & & & & \\
\hline 32 & $\mathrm{X}$ & $\mathrm{X}$ & $X$ & $\mathrm{X}$ & & & & & 7 & 3 & & 2 & & 5 & 2 & $\mathrm{sec}$ & $250 \mathrm{sec}$ & $\mathrm{X}$ & X & & $\mathrm{Y}$ & & $\mathrm{N}$ & $\mathrm{Y}$ & 2 & & & $\mathrm{X}$ & & & $\mathrm{X}$ & $\mathrm{X}$ & & & & & \\
\hline 33 & $\sim$ & & $X$ & $\mathrm{X}$ & $\mathrm{X}$ & $\bar{X}$ & & & 4 & & & 3 & & 3 & & sec. & 60 & $\mathrm{X}$ & X & & $\mathrm{X}$ & $\mathrm{X}$ & $\mathrm{N}$ & & 1 & & $\mathrm{~N}$ & & $\mathrm{X}$ & & & & & & & & \\
\hline 34 & & & & & $\bar{X}$ & & & & 4 & & & 3 & & 3 & 1 & sec. & $30 \mathrm{~min}$. & $\mathrm{X}$ & X & & $\mathrm{X}$ & $\mathrm{X}$ & $\mathrm{N}$ & & 1 & & $\mathrm{~N}$ & & $\mathrm{X}$ & & & & & & & & \\
\hline 35 & $\sim$ & $\sim$ & $X$ & $\mathrm{X}$ & & & & & 2 & 2 & & & & 2 & 2 & $\mathrm{sec}$ & 300 & $\mathrm{X}$ & X & & & $\mathrm{X}$ & $\mathrm{N}$ & & 2 & & & & $\mathrm{X}$ & & $\mathrm{X}$ & X & & & & & \\
\hline 36 & $\sim$ & & \begin{tabular}{l|l}
$\mathrm{X}$ & $\mathrm{X}$ \\
\end{tabular} & $\mathrm{X}$ & $\mathrm{X}$ & & & & 4 & & & 3 & & 3 & & sec. & 60 & $\mathrm{X}$ & X & & $\mathrm{X}$ & $\mathrm{X}$ & $\mathrm{N}$ & & 1 & & $\mathrm{~N}$ & & $\mathrm{X}$ & & & & & & & & \\
\hline 37 & $\mathrm{X}$ & $\mathrm{X}$ & \begin{tabular}{l|l}
$X$ & $X$
\end{tabular} & $\bar{x}$ & & & & & 10 & & & 10 & 10 & 9 & & -- & -- & $\mathrm{X}$ & & & $\mathrm{N}$ & $\mathrm{X}$ & & $\mathrm{X}$ & 2 & & & & & & $\mathrm{X}$ & $\mathrm{X}$ & & & & & \\
\hline 38 & $\mathrm{X}$ & $\mathrm{X}$ & \begin{tabular}{l|l}
$X$ & $X$ \\
\end{tabular} & $\mathrm{X}$ & & & & & & & & & & & & & & $\mathrm{X}$ & & & & & & & & & & & & & & & & & & & \\
\hline 39 & $\mathrm{X}$ & $\mathrm{X}$ & \begin{tabular}{l|l}
$X$ & $X$ \\
\end{tabular} & $\mathrm{X}$ & & & & & * & & & & & & & $\min$ & 60 & $\mathrm{X}$ & X & & $\mathrm{N}$ & & $\mathrm{N}$ & $\mathrm{X}$ & $1-3$ & & & $\mathrm{X}$ & & & $\mathrm{X}$ & $\mathrm{X}$ & & & & & \\
\hline 40 & $\mathrm{X}$ & $\mathrm{X}$ & & & & & & & 5 & 5 & & & & & & sec & $1000 \mathrm{sec}$ & $\mathrm{X}$ & & & $\mathrm{Y}$ & & & $\mathrm{Y}$ & & & & & & & & & & & & & \\
\hline 41 & $\mathrm{X}$ & $\mathrm{X}$ & & & & & $\mathrm{X}$ & $\mathrm{x}$ & 4 & 4 & & & 4 & 4 & - & $\min$ & 0.06 & $\mathrm{X}$ & X & & $\mathrm{X}$ & $\mathrm{X}$ & $\mathrm{N}$ & & 1 & & & & & & & $\mathrm{X}$ & & & & & \\
\hline 42 & $\mathrm{X}$ & $\mathrm{X}$ & & & & & & & 7 & 7 & & & 7 & 5 & $\begin{array}{ll}2 & 1\end{array}$ & $\min$ & $2-3$ & $\mathrm{X}$ & & & $\mathrm{X}$ & & $\mathrm{N}$ & $\mathrm{X}$ & & $\mathrm{X}$ & & & & & & & & & & & \\
\hline 43 & $\mathrm{X}$ & $\mathrm{X}$ & & & & & $\mathrm{X}$ & & 3 & & & 3 & 4 & 2 & 1 & & & $\mathrm{X}$ & & & $\mathrm{N}$ & & $\mathrm{N}$ & $\mathrm{X}$ & & & & & & & & & & & & & \\
\hline 44 & $\mathrm{X}$ & $\mathrm{X}$ & & & & & $\bar{X}$ & & 5 & 5 & & & 7 & 5 & & & & $\mathrm{X}$ & & & $\mathrm{Y}$ & & $\mathrm{N}$ & & & & & & & & & & & & & & \\
\hline 45 & $\mathrm{X}$ & $\mathrm{X}$ & & & & & $\bar{X}$ & & 13 & 13 & & & 16 & 7 & \begin{tabular}{l|l}
6 & $\mathrm{r}$
\end{tabular} & $\min$ & $10-30$ & $\mathrm{X}$ & $\mathrm{X}$ & & $\bar{N}$ & & $\mathrm{~N}$ & $\mathrm{X}$ & 4 & $\mathrm{X}$ & & & & & $\mathrm{X}$ & $\mathrm{X}$ & & & & $\mathrm{X}$ & \\
\hline 46 & $\mathrm{X}$ & $\mathrm{X}$ & & & & & $\bar{X}$ & & 6 & 6 & & & 6 & 5 & 1 & $\mathrm{n} / \mathrm{a}$ & $\mathrm{n} / \mathrm{a}$ & $\mathrm{X}$ & & & $\mathrm{N}$ & & $\mathrm{N}$ & $\mathrm{X}$ & & & & & & & & & & & & & \\
\hline 47 & $\mathrm{X}$ & $\mathrm{X}$ & & & & & $\mathrm{X}$ & & 5 & 5 & & & 5 & 4 & & $\mathrm{n} / \mathrm{a}$ & $\mathrm{n} / \mathrm{a}$ & $\mathrm{X}$ & & & $\mathrm{N}$ & & $\mathrm{N}$ & $\mathrm{X}$ & & & & & & & & & & & & & \\
\hline 48 & $\mathrm{X}$ & $\mathrm{X}$ & 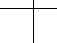 & & & & $\bar{X}$ & & 6 & 6 & & & 6 & 5 & \begin{tabular}{l|l}
1 & $\mathrm{r}$ \\
\end{tabular} & $\min$ & 1-Oct & $\mathrm{X}$ & & & $\mathrm{N}$ & $\mathrm{X}$ & $\mathrm{N}$ & $\mathrm{X}$ & & & & & & & & & & & & & \\
\hline 49 & $\mathrm{X}$ & $\mathrm{X}$ & - & r & $\mathrm{X}$ & $\mathrm{X}$ & & & 10 & & & 7 & & & & & & $\mathrm{X}$ & & & $\mathrm{X}$ & & $\mathrm{X}$ & & 1 & & & & $\mathrm{X}$ & & & & & & & & \\
\hline 50 & $\mathrm{X}$ & $\mathrm{X}$ & & & & & & $\mathrm{K}$ & & & & & & & & $\min$ & 8 & $\mathrm{X}$ & & & & & & & & & & & & & & & & & & & \\
\hline 51 & & & & & & & $\mathrm{X}$ & & 7 & & & 3 & 7 & 3 & 4 & $\mathrm{sec}$ & 300 & $\mathrm{X}$ & & & $\mathrm{X}$ & $\mathrm{X}$ & $\mathrm{N}$ & & 2 & & & & $\mathrm{X}$ & & $\mathrm{X}$ & $\mathrm{X}$ & & & & $\mathrm{X}$ & \\
\hline 52 & $\mathrm{X}$ & $\mathrm{X}$ & & & & & & $\mathrm{k}$ & 4 & & & & 4 & 4 & & * & $?$ & $\mathrm{X}$ & $\mathrm{X}$ & & & $\mathrm{X}$ & & $\mathrm{X}$ & 1 & & & & & & & & & $\mathrm{X}$ & & & \\
\hline 53 & $\mathrm{X}$ & $\mathrm{X}$ & $\mathrm{X}$ & & & $\mathrm{X}$ & & & 4 & & & & 4 & 4 & & & & $\mathrm{X}$ & & & & $\mathrm{X}$ & & $\mathrm{X}$ & 1 & & & & & & & & & $\mathrm{X}$ & & & \\
\hline 54 & $\mathrm{X}$ & & $X$ & $\mathrm{X}$ & & & & & 4 & 4 & & & & 4 & & & & & $\mathrm{X}$ & & $\mathrm{X}$ & $\mathrm{X}$ & $\mathrm{N}$ & & 1 & & & & & & & & & & & & \\
\hline 55 & $\mathrm{X}$ & $\mathrm{X}$ & & & & & & $\mathrm{K}$ & & & & & & & & -- & & $\mathrm{X}$ & & & & & & & 1 & & & & $\mathrm{X}$ & & & $\mathrm{X}$ & & $\mathrm{X}$ & & & \\
\hline 56 & $\mathrm{X}$ & $\mathrm{X}$ & & & $\mathrm{X}$ & $\mathrm{X}$ & $\bar{X}$ & & 4 & & & 4 & & 4 & & & & $\mathrm{X}$ & & & $\mathrm{Y}$ & $\mathrm{X}$ & & & & & & & & & & & & & & & \\
\hline 57 & $\mathrm{X}$ & & & & $\mathrm{X}$ & & & . & 5 & & & 5 & & 4 & $1 \mathrm{~m}$ & $\min$ & 4 & X & & & $\mathrm{N}$ & & $\mathrm{X}$ & $\mathrm{X}$ & 1 & & & & & & & & & $\mathrm{X}$ & & & \\
\hline 58 & $\mathrm{X}$ & $\mathrm{X} \mid 2$ & X & & & & & & 26 & 13 & & & 13 & 2 & & & $8-48$ & $\mathrm{X}$ & & & $\mathrm{N}$ & & & $\mathrm{X}$ & 0 & & & & & & & & & & & & \\
\hline 59 & $\mathrm{X}$ & $\mathrm{X}$ & $X$ & $\mathrm{X}$ & & & & & 5 & 1 & & & & 2 & \begin{tabular}{l|l}
2 & $\mathrm{~m}$ \\
\end{tabular} & $\min$ & $3,20,40$ & $\mathrm{X}$ & & & $\mathrm{N}$ & $\mathrm{X}$ & & $\mathrm{X}$ & 2 & & & $\mathrm{X}$ & & & & $\mathrm{X}$ & & $\mathrm{X}$ & & & \\
\hline
\end{tabular}


Table V: Model outputs, testing, results

\begin{tabular}{|c|c|c|c|c|c|c|c|c|c|c|c|c|c|c|c|c|c|c|c|c|c|c|c|c|c|c|c|}
\hline & & Outp & & & & & W & vali & date & & & & st $\mathrm{F}$ & Run & & & xpe & rime & enta & $1 \mathrm{Si}$ & imul & latio & on $\mathrm{F}$ & Run: & & & \\
\hline \# & 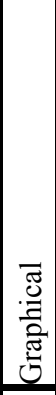 & 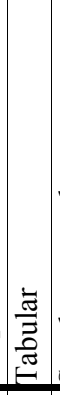 & 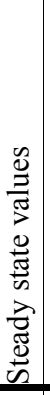 & 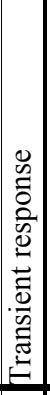 & 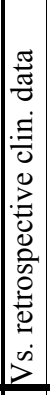 & 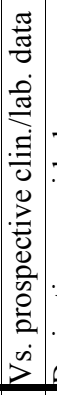 & 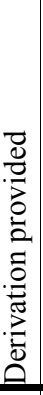 & 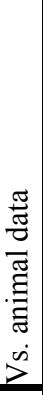 & 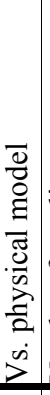 & 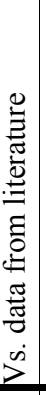 & 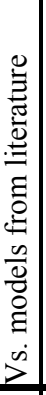 & 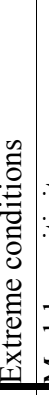 & 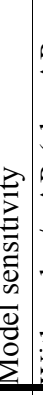 & 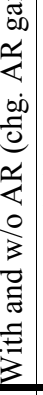 & 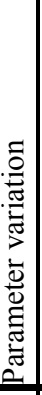 & 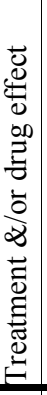 & 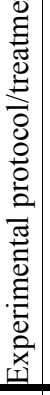 & 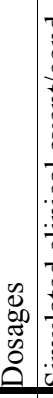 & 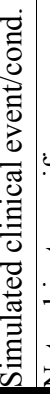 & 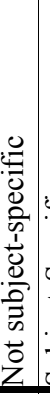 & 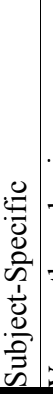 & 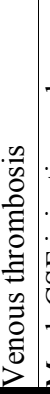 & 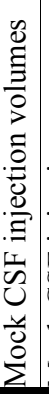 & 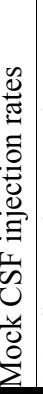 & 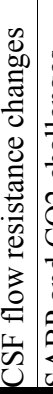 & 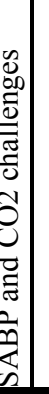 & Notes \\
\hline 1 & $\mathrm{X}$ & $\mathrm{X}$ & $\mathrm{X}$ & $\mathrm{X}$ & & $\mathrm{X}$ & & $\mathrm{X}$ & $\mathrm{X}$ & $\mathrm{X}$ & & & & & & & $\mathrm{X}$ & & & & $\mathrm{X}$ & & $\mathrm{X}$ & $\mathrm{X}$ & & & see TableV \\
\hline 2 & $\mathrm{X}$ & & & $\mathrm{X}$ & & & & $\mathrm{X}$ & & $\mathrm{X}$ & & & & & & & $\mathrm{X}$ & & & & $\mathrm{X}$ & & $\mathrm{X}$ & $X$ & & & see TableV \\
\hline 3 & $\mathrm{X}$ & & $\mathrm{X}$ & & & $\mathrm{X}$ & $\mathrm{X}$ & & $\mathrm{X}$ & & & & $X$ & & & & & & & & & & & & & & see TableV \\
\hline 4 & $\mathrm{X}$ & & $\mathrm{X}$ & & & & & & & $\mathrm{X}$ & & & & & & & & & & & & & $\mathrm{X}$ & $\mathrm{X}$ & & & see TableV \\
\hline 5 & $\mathrm{X}$ & $\mathrm{X}$ & & $\mathrm{x}$ & & & & $\mathrm{X}$ & & $\mathrm{X}$ & & & & & & & $\mathrm{X}$ & & & & & & $\mathrm{X}$ & $\mathrm{X}$ & & & Infusion rate vs. bolus injection \\
\hline 6 & $\mathrm{X}$ & & $\mathrm{X}$ & $\mathrm{X}$ & & & & & & $\mathrm{X}$ & & & & & & & & & $\mathrm{X}$ & & & & & & & & see TableV \\
\hline 7 & $\mathrm{X}$ & & $\mathrm{X}$ & $\mathrm{X}$ & $\mathrm{X}$ & & $\mathrm{X}$ & & & $\mathrm{X}$ & & & & & & & & & $\mathrm{X}$ & $\mathrm{X}$ & & & & & $\mathrm{X}$ & & see TableV \\
\hline 8 & $\mathrm{X}$ & & $\mathrm{X}$ & $\mathrm{X}$ & & & $\mathrm{X}$ & & & & & & & & & & & & $\mathrm{X}$ & $\mathrm{X}$ & & & $\mathrm{X}$ & & & & see TableV \\
\hline 9 & $\mathrm{X}$ & & & $\mathrm{X}$ & $X$ & & $\mathrm{X}$ & $\mathrm{X}$ & & $\mathrm{X}$ & & & & & & & & & & & & & & & & & see TableV \\
\hline 10 & & & & & & & $\mathrm{X}$ & & & & & & & & & & & & & & & & & & & & Difficult to see clinical relevance. \\
\hline 11 & $\mathrm{X}$ & $\mathrm{X}$ & $\mathrm{X}$ & $\mathrm{x}$ & & & & & & $\mathrm{X}$ & $\mathrm{X}$ & & & & $\mathrm{X}$ & & & & $\mathrm{X}$ & $\mathrm{X}$ & & & & & & & \\
\hline 12 & $\mathrm{X}$ & & & $\mathrm{x}$ & & & & & & $\mathrm{X}$ & & & & & & & & & $\mathrm{X}$ & $\mathrm{X}$ & & & & & & & $\begin{array}{l}\text { Possible hydrocephalus etiologies } \\
\text { tested. }\end{array}$ \\
\hline 13 & $\mathrm{X}$ & & & $\mathrm{x}$ & & $\mathrm{X}$ & & $\mathrm{X}$ & & & & & & & & $\mathrm{X}$ & & & & & $\mathrm{X}$ & & & & & & see TableV \\
\hline 14 & $\mathrm{X}$ & & & $\mathrm{x}$ & & & $\mathrm{X}$ & & & $\mathrm{X}$ & & & & & & & & & & $\mathrm{X}$ & & & & $\mathrm{X}$ & & & see TableV \\
\hline 15 & $\mathrm{X}$ & & & $\mathrm{X}$ & & & & & & $\mathrm{X}$ & & & & & $\mathrm{X}$ & & & & & $\mathrm{X}$ & & $\mathrm{X}$ & $\mathrm{X}$ & $\mathrm{X}$ & & & $\begin{array}{l}\text { Assertion in discussion is an } \\
\text { overstatement. }\end{array}$ \\
\hline 16 & $\mathrm{X}$ & & $\mathrm{X}$ & $\mathrm{X}$ & & & & & & & & & & $\mathrm{X}$ & & & & & & & & & $\mathrm{X}$ & $\mathrm{X}$ & & & see TableV \\
\hline 17 & $X$ & & $\mathrm{X}$ & $\mathrm{X}$ & & & $\mathrm{X}$ & & & $\mathrm{X}$ & & & & & $\mathrm{X}$ & & & & $\mathrm{X}$ & $\mathrm{X}$ & & & & & & & see TableV \\
\hline 18 & $\mathrm{X}$ & & & $\mathrm{X}$ & & & $\mathrm{X}$ & $\mathrm{X}$ & & $\mathrm{X}$ & & & & $\mathrm{X}$ & & & & & $\mathrm{X}$ & $\mathrm{X}$ & & & & & & & see TableV \\
\hline 19 & $\mathrm{X}$ & & & $\mathrm{x}$ & & & & $\mathrm{X}$ & & $\mathrm{X}$ & & & & $\mathrm{X}$ & & & & & $\mathrm{X}$ & $\mathrm{X}$ & & & & & & & see TableV \\
\hline 20 & $\mathrm{X}$ & $\mathrm{X}$ & & $\mathrm{x}$ & & $\mathrm{X}$ & & & & & & & & & & & & & $\mathrm{X}$ & & $\mathrm{X}$ & & $\mathrm{X}$ & & & & $\begin{array}{l}\text { One key assumption is pressure } \\
\text { dependent CSF formation. }\end{array}$ \\
\hline 21 & $\mathrm{X}$ & & & $\mathrm{X}$ & & & & $\mathrm{X}$ & & $\mathrm{X}$ & & & & $\mathrm{X}$ & $\mathrm{X}$ & & & & $\mathrm{X}$ & $\mathrm{X}$ & & & & & & & see TableV \\
\hline 22 & $\mathrm{X}$ & & $\mathrm{X}$ & $\mathrm{X}$ & & & & & & $\mathrm{X}$ & $\mathrm{X}$ & & & & & & & & $\mathrm{X}$ & $\mathrm{X}$ & & & $\mathrm{X}$ & $\mathrm{X}$ & & & Press. dependent CSF formation \\
\hline 23 & $\mathrm{X}$ & $\mathrm{X}$ & $\mathrm{X}$ & $\mathrm{X}$ & & $\mathrm{X}$ & & & & $\mathrm{X}$ & & & & & & & & & $\mathrm{X}$ & & $\mathrm{X}$ & & $\mathrm{X}$ & & & & see TableV \\
\hline 24 & $\mathrm{X}$ & $\mathrm{X}$ & & $\mathrm{X}$ & & $\mathrm{X}$ & & & & & & & $\mathrm{X}$ & $\mathrm{X}$ & $\mathrm{x}$ & & $\mathrm{X}$ & & $\mathrm{X}$ & & $\mathrm{X}$ & & & & & & see TableV \\
\hline 24 & $\mathrm{X}$ & & $\mathrm{X}$ & & & & & & & $\mathrm{X}$ & & $\mathrm{X}$ & $\mathrm{X}$ & $\mathrm{X}$ & $\mathrm{X}$ & & & & & $\mathrm{X}$ & & & & & & & Limited validation (subsequent paper) \\
\hline 25 & $\mathrm{X}$ & & $\mathrm{X}$ & $\mathrm{X}$ & & & & & & $\mathrm{X}$ & & $\mathrm{X}$ & & & $\mathrm{X}$ & & & & & $\mathrm{X}$ & & & & & & & see TableV \\
\hline 27 & $\mathrm{X}$ & $\mathrm{X}$ & $\mathrm{X}$ & & & & $\mathrm{X}$ & & & $\mathrm{X}$ & & & $\mathrm{X}$ & $\mathrm{X}$ & $\mathrm{x}$ & & & & $\mathrm{X}$ & $\mathrm{X}$ & & & & & & & see TableV \\
\hline 28 & $\mathrm{X}$ & & $\mathrm{X}$ & $\mathrm{x}$ & & $\mathrm{X}$ & & & & & & & & & $\mathrm{x}$ & & $\mathrm{X}$ & & $\mathrm{X}$ & $\mathrm{X}$ & & & & & & & \\
\hline 29 & $\mathrm{X}$ & $\mathrm{X}$ & $\mathrm{X}$ & $\mathrm{X}$ & & $\mathrm{X}$ & & & & $\mathrm{X}$ & & & & & & & & & $\mathrm{X}$ & & $\mathrm{X}$ & & & & & $x \mid \frac{c}{8}$ & $\begin{array}{l}\text { Contrasts } \mathrm{CO} 2 \text { reactivity and } \mathrm{AR} \\
\text { gain/time constant }\end{array}$ \\
\hline 30 & $\mathrm{X}$ & & $\mathrm{X}$ & $\mathrm{X}$ & & $\mathrm{X}$ & & & & $\mathrm{X}$ & & & $\mathrm{X}$ & & & & & & $\mathrm{X}$ & & $\mathrm{X}$ & & & & & $\mathrm{x} \mid \mathrm{s}$ & Some model details not provided \\
\hline 31 & $\mathrm{X}$ & & $\mathrm{X}$ & $\mathrm{X}$ & & & $\mathrm{X}$ & $\mathrm{X}$ & & $\mathrm{X}$ & & & & $\mathrm{X}$ & & & & & $\mathrm{X}$ & $\mathrm{X}$ & & & & & & & see TableV \\
\hline 32 & $\mathrm{X}$ & & $\mathrm{X}$ & $\mathrm{X}$ & & & & & & & & & $\mathrm{X}$ & $\mathrm{X}$ & $\mathrm{x}$ & & & & & $\mathrm{X}$ & & & & & & & see TableV \\
\hline 33 & $\mathrm{X}$ & & $\mathrm{X}$ & $\mathrm{X}$ & & $\mathrm{X}$ & & & & $\mathrm{X}$ & & & & $\mathrm{X}$ & $\mathrm{x}$ & & $\mathrm{X}$ & & & & & & & & & & see TableV \\
\hline 34 & $\mathrm{X}$ & & $\mathrm{X}$ & & & $\sim$ & & & & $\sim$ & & & & & & & & & & & & & & & & & $\begin{array}{l}\text { Limited validation; demonstration runs } \\
\text { only }\end{array}$ \\
\hline 35 & $\mathrm{X}$ & & & $\mathrm{X}$ & $\mathrm{X}$ & & & $\mathrm{X}$ & & & & & & & & & & & $\mathrm{X}$ & $\mathrm{X}$ & & & & & & & see TableV \\
\hline
\end{tabular}


Table V: Model outputs, testing, results

\begin{tabular}{|c|c|c|c|c|c|c|c|c|c|c|c|c|c|c|c|c|c|c|c|c|c|c|c|c|c|c|}
\hline & & Dutp & & & & & $\mathrm{W} \mathrm{v}$ & alic & date & & & & est $\mathrm{F}$ & Run & & & xper & iimes & ntal & $\mathrm{Sil}$ & mula & atio & $\mathrm{n} R$ & & & \\
\hline \# & 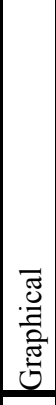 & 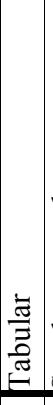 & 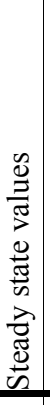 & 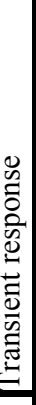 & 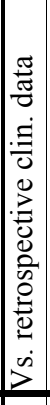 & 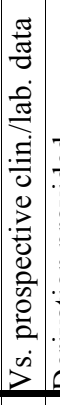 & 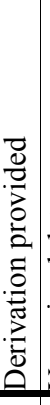 & 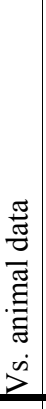 & 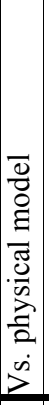 & 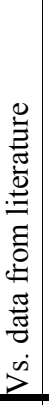 & 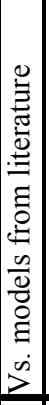 & 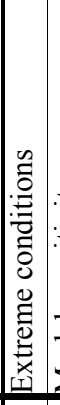 & 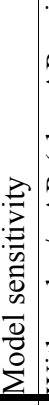 & 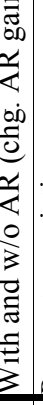 & 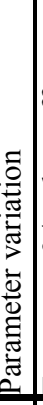 & 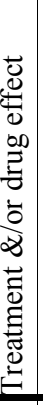 & 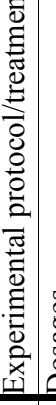 & 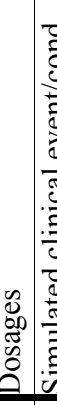 & 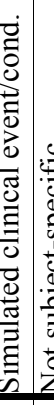 & 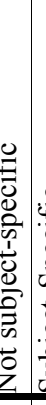 & 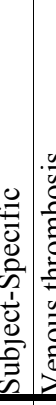 & 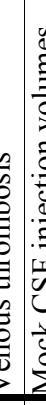 & & 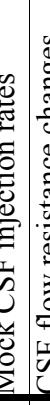 & 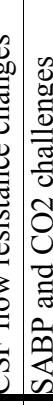 & Notes \\
\hline 36 & $\mathrm{X}$ & & & $\mathrm{X}$ & & & & & & & & & & $\mathrm{X}$ & & & $\mathrm{X}$ & & & & & & & & & $\begin{array}{l}\text { Models help with clinical } \\
\text { interpretation. }\end{array}$ \\
\hline 37 & $\mathrm{X}$ & & $\mathrm{X}$ & & & & $\mathrm{X}$ & & & & & & & $\mathrm{x}$ & $\mathrm{X}$ & & & & $\mathrm{X} \mid \mathrm{x}$ & $\mathrm{X}$ & & & & & & Very Nice "cartoon" of system/model. \\
\hline 38 & $\mathrm{X}$ & & $\mathrm{X}$ & & & & & & $\mathrm{X}$ & & & & & & & & & & & & & & & & & see TableV \\
\hline 39 & $X$ & & & $\mathrm{X}$ & & $\mathrm{X}$ & $\mathrm{X}$ & $\mathrm{X}$ & $\mathrm{X}$ & $\mathrm{X}$ & $\mathrm{X}$ & & & & & & $\mathrm{X}$ & & \begin{tabular}{l|l}
$X$ & 1 \\
$x$
\end{tabular} & $\mathrm{X}$ & & L & $x$ & & & see TableV \\
\hline 40 & $\mathrm{X}$ & & & $\mathrm{X}$ & & & $\mathrm{X}$ & & & & & & & & & & & & & & & & & & & see TableV \\
\hline 41 & $X$ & & $\mathrm{X}$ & $X$ & & & $\mathrm{X}$ & & & & $\mathrm{X}$ & & & $\mathrm{X}$ & & & & & & & & & & & & see TableV \\
\hline 42 & $\mathrm{X}$ & $\mathrm{X}$ & & $X$ & & & $\mathrm{X}$ & $\mathrm{X}$ & & & & & & & & & $\mathrm{X}$ & & & & $\mathrm{X}$ & $y$ & $\mathrm{x}$ & & & see TableV \\
\hline 43 & $X$ & & $\mathrm{X}$ & & & & $\mathrm{X}$ & & & $\mathrm{X}$ & & & & & & & & & & $X$ & & & & $X$ & & see TableV \\
\hline 44 & & & & & & & $\mathrm{X}$ & & & $\mathrm{X}$ & $\mathrm{X}$ & & & & & & & & & $\mathrm{X}$ & & & & $\mathrm{X}$ & & \\
\hline 45 & $X$ & & & $\mathrm{X}$ & & & $\mathrm{X}$ & & & $\mathrm{X}$ & $\mathrm{X}$ & $\mathrm{X}$ & $\mathrm{X}$ & $\mathrm{X}$ & $\mathrm{X}$ & & & & $\mathrm{X}$ & $X$ & & $y$ & $\mathrm{x}$ & & & see TableV \\
\hline 46 & $\mathrm{X}$ & $\mathrm{X}$ & $\mathrm{X}$ & & & & $\mathrm{X}$ & & & $\mathrm{X}$ & & & $\mathrm{X}$ & & $\mathrm{X}$ & & & & $\mathrm{X}$ & $\mathrm{X}$ & & & & 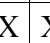 & $X$ & \\
\hline 47 & $\mathrm{X}$ & & $\mathrm{X}$ & & & & $\mathrm{X}$ & & & $\mathrm{X}$ & & & $\mathrm{X}$ & & $\mathrm{x}$ & $\mathrm{X}$ & & & $\mathrm{X}$ & $\mathrm{X}$ & & & 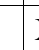 & \begin{tabular}{l|l}
$X$ & $Y$ \\
\end{tabular} & $\mathrm{X}$ & \\
\hline 48 & $\mathrm{X}$ & $\mathrm{X}$ & $\mathrm{X}$ & $\mathrm{X}$ & & & & & & $\mathrm{X}$ & & & $\mathrm{X}$ & & $\mathrm{X}$ & & & & $\mathrm{X}$ & & $\mathrm{X}$ & & & \begin{tabular}{l|l}
$X$ & $Y$
\end{tabular} & $\mathrm{x}$ & 3 subjects \\
\hline 49 & $\mathrm{X}$ & & $X$ & $\mathrm{X}$ & $\mathrm{X}$ & & & & & & & & & $\mathrm{X}$ & & $\mathrm{X}$ & & $\mathrm{X}$ & & $\mathrm{X}$ & & & & & & see TableV \\
\hline 50 & $\mathrm{X}$ & & & $\mathrm{X}$ & & & & & & $\mathrm{X}$ & & & & & & & & & $\mathrm{X}$ & & & & & & & see TableV \\
\hline 51 & $\mathrm{X}$ & $\mathrm{X}$ & & $\mathrm{X}$ & $\mathrm{X}$ & & & & & $\mathrm{X}$ & & & & $\mathrm{X}$ & & $\mathrm{X}$ & & & $\mathrm{X}$ & $\mathrm{X}$ & & & & & & see TableV \\
\hline 52 & $X$ & $\mathrm{X}$ & $\mathrm{X}$ & & & & & & & $X$ & & & & $\mathrm{X}$ & $\mathrm{X}$ & & & & & $\mathrm{X}$ & & & & & & see TableV \\
\hline 53 & $X$ & $\mathrm{X}$ & $\mathrm{X}$ & & $\mathrm{X}$ & & & $\mathrm{X}$ & & $\mathrm{X}$ & & & & $\mathrm{X}$ & $\mathrm{X}$ & & & & $\mathrm{X}$ & $\mathrm{X}$ & & & & & & Black box approach \\
\hline 54 & & & & & & & & & & & & & & & & & & & & & & & & & & Not simulation, but very relevant \\
\hline 55 & $\mathrm{X}$ & & $\mathrm{X}$ & & & & & & & $\mathrm{X}$ & & & & & & & & & $\mathrm{X}$ & & & & & & & see TableV \\
\hline 56 & $\mathrm{X}$ & & $\mathrm{X}$ & & & & $\mathrm{X}$ & & & $\mathrm{X}$ & $\mathrm{X}$ & & & & & & & & & & $\mathrm{x}$ & $\mathrm{X}$ & & & & see TableV \\
\hline 57 & $\mathrm{X}$ & & & $\mathrm{X}$ & $\mathrm{X}$ & & & & & & & & & & & & $\mathrm{X}$ & & & & $\mathrm{X}$ & & & & & \\
\hline 58 & $\mathrm{X}$ & $\mathrm{X}$ & $\mathrm{X}$ & $\mathrm{X}$ & & & & & & $\mathrm{X}$ & $\mathrm{X}$ & & & & & & $\mathrm{X}$ & & 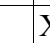 & $\bar{X}$ & & & 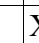 & $\mathrm{X}$ & & see Table V \\
\hline 59 & $\mathrm{X}$ & $\mathrm{X}$ & & $\mathrm{X}$ & $\mathrm{X}$ & $\mathrm{X}$ & & & & $\mathrm{X}$ & $\mathrm{X}$ & $\mathrm{X}$ & & & & $\mathrm{X}$ & $\mathrm{X}$ & $\mathrm{X}$ & & $\mathrm{I}$ & $\mathrm{X}$ & & & & & \\
\hline
\end{tabular}




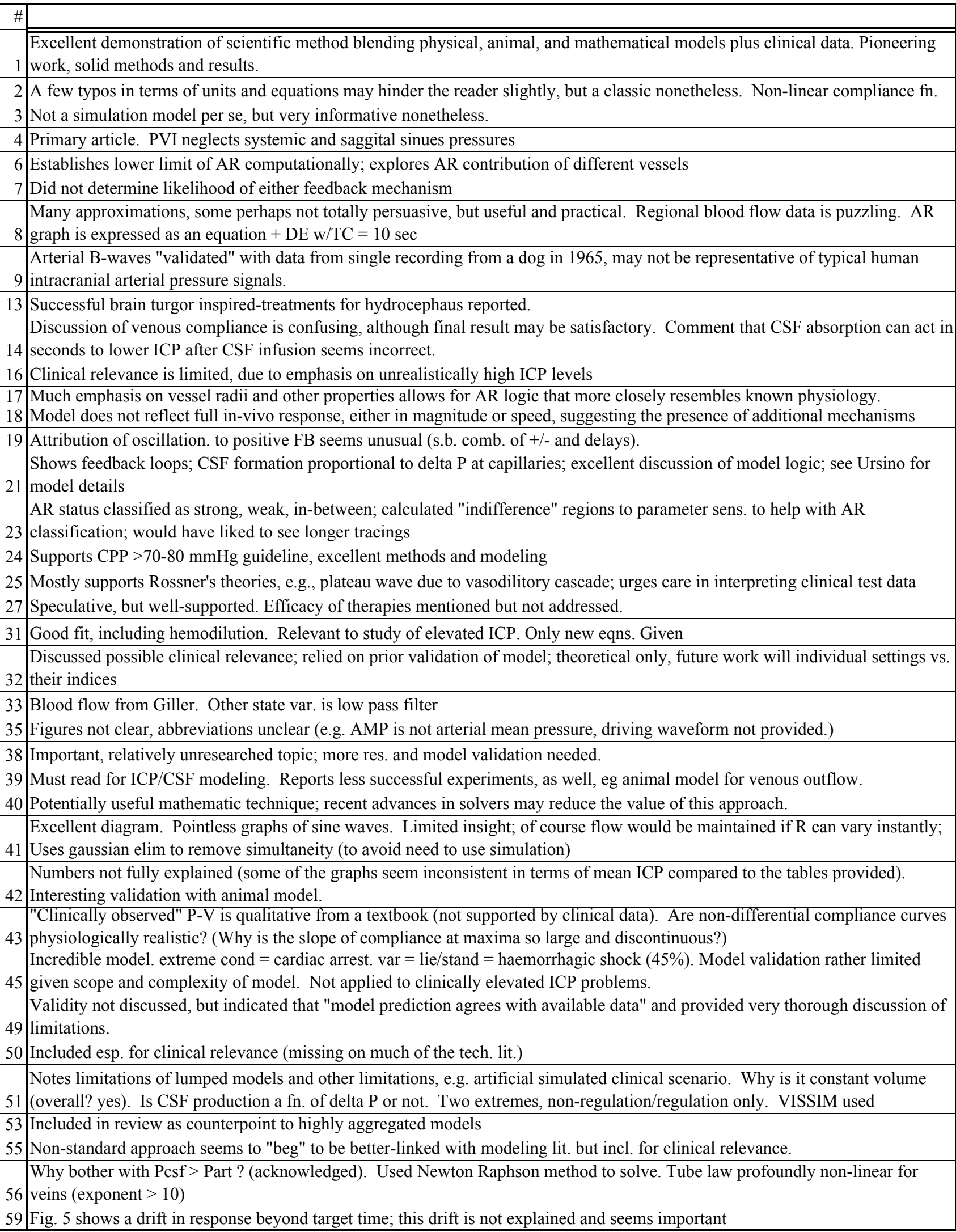

